\title{
RESEARCH
}

Open Access

\section{Applying an environmental public health lens to the industrialization of food animal production in ten low- and middle-income countries}

Yukyan Lam', Jillian P. Fry ${ }^{1,2,3}$ and Keeve E. Nachman ${ }^{1,2,45^{*}}$ (D)

\begin{abstract}
Background: Industrial food animal production (IFAP) is characterized by dense animal housing, high throughput, specialization, vertical integration, and corporate consolidation. Research in high-income countries has documented impacts on public health, the environment, and animal welfare. IFAP is proliferating in some low- and middle-income countries (LMICs), where increased consumption of animal-source foods has occurred alongside rising incomes and efforts to address undernutrition. However, in these countries IFAP's negative externalities could be amplified by inadequate infrastructure and resources to document issues and implement controls.
\end{abstract}

Methods: Using UN FAOSTAT data, we selected ten LMICs where food animal production is expanding and assessed patterns of IFAP growth. We conducted a mixed methods review to explore factors affecting growth, evidence of impacts, and information gaps; we searched several databases for sources in English, Spanish, and Portuguese. Data were extracted from 450+ sources, comprising peer-reviewed literature, government documents, NGO reports, and news articles.

Results: In the selected LMICs, not only has livestock production increased, but the nature of expansion appears to have involved industrialized methods, to varying extents based on species and location. Expansion was promoted in some countries by explicit government policies. Animal densities, corporate structure, and pharmaceutical reliance in some areas mirrored conditions found in high-income countries. There were many reported weaknesses in regulation and capacity for enforcement surrounding production and animal welfare. Global trade increasingly influences movement of and access to inputs such as feed. There was a nascent, compelling body of scientific literature documenting IFAP's negative environmental and public health externalities in some countries.

(Continued on next page)

\footnotetext{
* Correspondence: knachman@jhu.edu

'Johns Hopkins Center for a Livable Future, Johns Hopkins Bloomberg

School of Public Health, 111 Market Place, Suite 840, Baltimore, MD 21202,

USA

${ }^{2}$ Department of Environmental Health \& Engineering, Johns Hopkins

Bloomberg School of Public Health, 615 N. Wolfe St., Baltimore, MD 21205,

USA

Full list of author information is available at the end of the article
}

(c) The Author(s). 2019 Open Access This article is distributed under the terms of the Creative Commons Attribution 4.0 International License (http://creativecommons.org/licenses/by/4.0/), which permits unrestricted use, distribution, and reproduction in any medium, provided you give appropriate credit to the original author(s) and the source, provide a link to the Creative Commons license, and indicate if changes were made. The Creative Commons Public Domain Dedication waiver (http://creativecommons.org/publicdomain/zero/1.0/) applies to the data made available in this article, unless otherwise stated. 


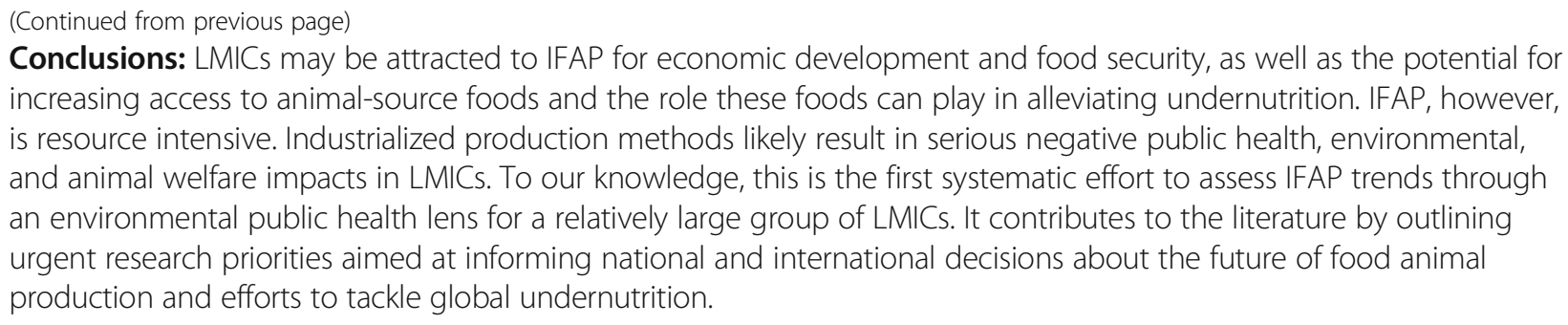
increasing access to animal-source foods and the role these foods can play in alleviating undernutrition. IFAP, however, is resource intensive. Industrialized production methods likely result in serious negative public health, environmental, and animal welfare impacts in LMICs. To our knowledge, this is the first systematic effort to assess IFAP trends through an environmental public health lens for a relatively large group of LMICs. It contributes to the literature by outlining urgent research priorities aimed at informing national and international decisions about the future of food animal production and efforts to tackle global undernutrition.

Keywords: Industrial food animal production, Lower and middle-income countries, Meat, Animal feed, Land use, Policy analysis

\section{Background}

As appetites for animal products increase globally, the practice of industrial food animal production (IFAP) has expanded in many parts of the world. This mode of production is characterized by high throughput methods that involve housing thousands to millions of animals per year in close proximity at a single location [1]. Waste management at these facilities is typically handled in a manner that leads to unhygienic production conditions. In the case of chickens raised for meat, dry manure from production is only partially removed between flocks; for other species, waste is typically handled in liquid form and temporarily stored in manure lagoons before being applied to agricultural land as fertilizer, sometimes exceeding appropriate agronomic rates [2-5]. The manure harbors a variety of microbiological and chemical agents, many of which can pose health risks when released into the environment, especially among persons who may encounter them in air, water or soil, or who may ingest them when consuming animal products [6-15]. These production methods often rely on an array of veterinary pharmaceuticals, including antibiotics from classes important to human medicine, and arsenic-based drugs [16-18]. The use of some of these compounds has been shown to select for bacteria that can cause antibiotic resistant infections in exposed persons.

While often purported to be an efficient means of producing animal protein, evidence exists to suggest that IFAP is responsible for significant public health and ecological burdens. In part due to the inputs required, but also due to the magnitude of waste produced by this system, IFAP facilities are responsible for the generation and release of myriad environmental health hazards that have been demonstrated to impact the health of animal house workers, community residents, persons consuming animal products derived from this system, and the global ecosystem. Evidence suggests that the industrialized model of animal production also can have serious consequences for the welfare of animals raised within this system [1, 19-22].
Occupational exposures faced by employees of IFAP facilities are well documented, as workers have the most contact with the hazards generated by the production system. Numerous studies have documented increased risks of respiratory disease [11, 23-27], as well as colonization with antimicrobial-resistant bacteria among animal house workers [28-31].

Hazards generated on-site have also been shown to leave the property of the production facility and expose persons residing on adjacent properties and in surrounding communities [8, 32, 33]. These releases can occur as a result of ventilation fans used to moderate the temperature of the facility and through the discharge of animal wastes, both through direct discharge and through management practices used to transport wastes away from production facilities and onto agricultural fields [5, 34]. Animal transport trucks and other non-domesticated vectors like flies have been shown to transport antibiotic- resistant bacteria into communities [35, 36]. Studies of members of communities proximate to IFAP have found significant associations with respiratory disease, antibiotic-resistant bacterial carriage and infection, mental health outcomes, and other adverse health conditions $[7,8,12-15,37-43]$.

The production of animals is resource intensive, and requires large quantities of feed and water [44]. Beyond the direct impacts felt by those working in and living near IFAP facilities, research has documented the global impact of feed and water provisioning for animal production, and how it may contribute to worsening climate and water availability crises [45-47].

The industrialized method of animal production was first developed in the United States [1], and following its establishment, similar production operations have become commonplace in other high-income countries, supporting diets that are relatively high in animal-based food as compared to the rest of the world [48]. In many lower- and middle-income countries (LMICs), however, animal-based food consumption levels are low, mainly due to lack of availability and poverty; as incomes rise in 
these countries a corresponding increase has been observed in appetites for animal-based foods [48, 49].

Increased consumption of animal-based foods is an important component of efforts to address the burden of undernutrition globally. Stunting and other forms of undernutrition are still widespread and remain a leading cause of high morbidity and mortality in LMICs [50]. In 2017 , the global prevalence of stunting was $22.2 \%$, with regional prevalences of $23.2 \%$ for Asia, 9.6\% for Latin America and the Caribbean, and $30.3 \%$ for Africa [50]. Further, stunting has irreversible effects, in particular on cognitive development, with repercussions on childhood school performance and economic productivity in adult life, as well as on maternal and neonatal mortality and morbidity when stunted children themselves bear children [51]. Children who are undernourished in their first 2 years of life also face higher risk of chronic diseases when they experience rapid weight gain in later childhood or adulthood [52]. Higher intake of animal-source foods in the first 1,000 days of life is an essential strategy for alleviating these burdens $[53,54]$.

Given this challenge, LMICs may indeed be interested in increasing the availability of animal-source foods by increasing domestic food animal production. Prior evidence suggests that adoption of industrialized production methods is increasing in LMICs [55], occurring alongside the global expansion of western-owned food animal production companies [56]. Further, research has shown that rising disposable incomes are associated with enhanced dietary diversity, including the addition of animal-source foods [57]. Considering the negative externalities described above, the reliance on industrialized methods in LMICs for increasing the availability of animal-source foods raises concerns because people living in LMICs already bear the largest burden of morbidity and mortality caused by environmental contamination, in part due to a lack of resources for pollution control infrastructure and effective regulatory controls [58]. The purpose of this paper is to assess the current state of IFAP growth in a relatively large and geographically diverse set of LMICs, with special attention on the environmental public health impacts that may be unintended consequences of this trend. Our mixed methods review describes features of IFAP growth in these countries, identifies factors enabling or inhibiting industry expansion, synthesizes evidence of impacts, and characterizes key information gaps.

\section{Methods}

The research methodology followed three main steps: country selection, literature search, and data extraction. Methods, described in brief below, are elaborated in greater detail elsewhere [59].

\section{Country selection}

We used a series of analytical steps and metrics to select ten low- and middle-income countries that provided geographic variability. First, we excluded high-income countries, based on World Bank designations, and countries with less than one million inhabitants. Then, based on each country's livestock numbers as reported by the United Nations Food and Agriculture Organization (FAO) from 2013, we calculated the total animal units (AUs) for cattle, chickens, and pigs, using conversion factors previously applied by the US EPA. We also calculated AUs per agricultural area to derive AU density. Based on the metrics of total AUs and AU density, we selected Ethiopia, Myanmar, India, and Vietnam. Based on total AUs, we selected Brazil and China. Finally, considering species- specific production, total AUs, and the goal of achieving reasonable geographic coverage, we added Mexico, Turkey, Kenya, and Uganda.

\section{Literature search}

A mixed methods review was used to identify i) peerreviewed literature, ii) non-peer reviewed sources (i.e., report from a non-governmental organization or government agency), and iii) news articles; this approach combines review methods and source types to provide a broader understanding of a topic than a review based solely on the peer-reviewed literature [60]. We conducted searches for information in English, Portuguese, and Spanish in 2015. The date restrictions that we applied varied by source, but in general we restricted to sources published from 2000 onward. We searched for peer-reviewed academic articles and non-peer reviewed reports using PubMed (no date restriction), Scopus, the US Department of Agriculture's Agricultural Online Access (AGRICOLA) database, Google Scholar, and Google. Specific search terms, by source/database, are listed in the appendix. For news articles, we searched Google News (restricted to 2010 onward), Global Meat News, Feed Navigator, and Environmental Health News-Above the Fold (no date restriction for these latter sources).

The goal was to balance breadth and depth across and within countries to the extent possible. Thus, for countries yielding less information, we looked further back in time for references. For countries yielding numerous recent references, we cut off the search at more recent dates, after obtaining adequate references to cover the topics in sufficient depth. In addition to source language (English, Portuguese, or Spanish) and publication date (as described above), additional inclusion criteria were that there be clear authorship (including institutional authors) and subject matter relevance. Personal blogs and opinion pieces were excluded. Overall, we cast a wide net in our search strategy to ensure that we could capture sufficient information about an evolving situation, 
for which there has been limited attention and resources for research.

\section{Data extraction and analysis}

Of the documents collected using the search strategy described above, approximately $10 \%$ were excluded upon further examination because, notwithstanding their titles/abstracts, they lacked relevant information or were insufficiently reliable or comprehensible. Data were extracted from the remaining references using a template that contained the following categories: basic information about the document; a summary; numerical projections on food animal production; livestock industry characteristics; impacts of IFAP; public engagement with food animal production issues; and comments about the quality of the reference. In total, information was extracted from over 450 documents. The number and type of documents are shown by country in Table 1 .

Information was analyzed first by country, and then synthesized by theme, following the above-mentioned categories. The quality of the documents was taken into account during synthesis in that we relied more heavily on sources in the peer-reviewed scientific literature, those issued by intergovernmental, government, and non-governmental organizations, and those that were relatively recent.

\section{Results}

Results from reviewing the country sources are synthesized below by topic. We start with describing the policy and regulatory landscape around food animal production, and then outline general features and notable trends regarding specific aspects of production. These range from industry characteristics to production practices and inputs to IFAP impacts.

Table 1 Sources for data extraction

\begin{tabular}{llll}
\hline Country & Journal articles & News articles & $\begin{array}{l}\text { Others (e.g., NGO/IGO reports, } \\
\text { conference papers, government } \\
\text { sources) }\end{array}$ \\
\hline Brazil & 26 & 27 & 20 \\
China & 43 & 42 & 18 \\
Ethiopia & 28 & 1 & 14 \\
India & 15 & 16 & 19 \\
Kenya & 13 & 3 & 5 \\
Mexico & 10 & 7 & 6 \\
Myanmar & 5 & 2 & 5 \\
Turkey & 20 & 2 & 12 \\
Uganda & 14 & 11 & 16 \\
Vietnam & 23 & 9 & 32 \\
\hline
\end{tabular}

\section{Domestic policies}

\section{Policies driving IFAP in these LMICS}

We found consistent evidence that domestic policies have played an important role in the industrialization of food animal production in low- and middle-income countries. Policies include facilitating access to production inputs and services, providing technical assistance, subsidized credit, low-interest loans, tax breaks, and other forms of financial assistance, reducing trade barriers, strengthening private property rights, land leases, and land reform. Sources referenced such policies in Brazil [61], China [6266], India [67, 68], Mexico [69-72], Turkey [73-75], and Vietnam [76-83].

The benefits provided are often available only to production units operating at a minimum scale. This can result in a "distorting" of the market to the detriment of smaller-scale producers [67]. For example, in China, the official designation of "dragonhead enterprise" is given to companies meeting a certain scale of production, technology use, and management, and enables those companies to receive subsidies and tax breaks from various levels of government and confers greater legitimacy $[64,66]$. Other examples include the state of Uttar Pradesh in India, where subsidies of up to $\$ 830,000$ US dollars were provided to farms with at least 10,000 parent units of broiler chickens [68], and the East and Southeast Annatolia regions of Turkey, where the government covered $30 \%$ of construction and $40 \%$ of breeding equipment costs for new cattle stock farms containing at least 50 heads $[75,84]$.

Moreover, the policies often fit within overarching national livestock development strategies that promote expansion, vertical integration, consolidation, and intensification of food animal production. In China, the country's twelfth "Five-Year Food Industry Plan (2010-2015)" envisioned a 50\% reduction in smallscale pork slaughterhouses by 2015 through mergers and acquisitions [85]. Vietnam's 2020 national livestock development plan promotes industrialization and integration, and aims for large- scale intensive livestock farms to produce $70 \%$ of the country's meat, and for industrial slaughtering to account for approximately $35 \%$ of the meat supply by 2020 [76].

In the region of sub-Saharan Africa, the national governments of Ethiopia, Uganda, and Kenya also encourage expansion of livestock production; however, it appears emphasis has been on rural development and improved livelihoods instead of scale or industrialization [86-89]. In Ethiopia, the government's "National Livestock Development Projects" focus on small-scale operations that increase household income through 'improved' livestock rearing, rather than on increased output [86]. In Uganda, the "National Agriculture Policy" launched by the president in 2014 specifies, as part of its six objectives, increased food 
security, farming household income, and human resources [89]. In these contexts, government and non-governmental actors have provided extension services, training, and other support to help farmers increase productivity and efficiency $[87,88,90-92]$.

\section{Regulations}

Another major theme emerging from our review is concern over insufficient or inadequate regulation of food animal production in low- and middle-income countries experiencing IFAP expansion. One principal domain of concern is the oversight of inputs used in raising livestock, including antimicrobial drugs and other growthpromoting compounds, which has implications for public health and food safety. Despite some recognition of the problem and government efforts to address it, ineffective monitoring and/or inadequate regulations have persisted as challenges in countries like China [93-95], Ethiopia [96], India [97], Myanmar [98], Uganda [92], and Vietnam [76, 83, 99-101].

Another key domain pertains to the environmental impacts of food animal production activities, including wastewater discharge, manure management, and disposal of dead animals. Various sources attest that regulations in this domain have been difficult to enforce, too lax, or absent altogether in Brazil [67, 102], China [103105], India [67], Kenya [106], Mexico [107], Myanmar [83], and Turkey [108-110]. For example, two studies in Turkey documented non-compliance with environmental regulations regarding storage of animal waste [109, 110], while a study in Mexico noted a rise in confined animal feeding operations-"CAFOs" - but no standard definition of a "CAFO" or regulations on minimum distances that these operations have to be set back from residential areas [107]. According to a comparative legal study, animal agriculture in Brazil is often exempted from animal and environmental laws, which have weak enforcement mechanisms, and an official estimate of $40 \%$ of animal farms operate informally, and therefore outside the sphere of regulation [111].

A few sources also highlighted weak regulations or inadequate enforcement of regulations to protect animal welfare, specifically in Brazil [111, 112], China [105], and Turkey [113]. For example, some standards on animal welfare in Brazil are only voluntary [112], while another norm that penalizes animal cruelty does not cover slaughter [111].

Difficulties in regulating food animal production were sometimes ascribed to inefficient inter-institutional collaboration [83, 93, 100], reliance on local government enforcers [114, 115], and disparate standards enacted across country regions [102]. However, the regulatory landscape was described as evolving in countries like China, where three new laws came into effect in 2015 aimed at addressing food safety, environmental impacts, and advertising and labeling [116].

\section{Industry characteristics Larger, more profit-oriented operations}

Across the countries studied, the upsurge of larger commercial operations raising only one type of livestock animal has occurred alongside a decline in smaller subsistence- oriented farms over the past few decades. We found many sources that sought to classify a facility's scale of production based on the type and number of live animals raised at any given time or per season/year. Despite this tendency, the thresholds are not uniform across countries. For example, a typology for broiler production in Brazil deems "small" producers to be those with less than 10,000 broilers and "large" producers to be those with 10,000 broilers or more [67]. Meanwhile, in Vietnam, units with up to 2,000 broilers are considered "small-" or "medium-scale," and those with 2,000 or more are considered "intensive" and "large-scale" [117]. There is a tendency to divide animal operations by scale and apply labels to them, but caution should be taken in interpreting these labels, since they are dependent on context and may even vary with time. For this reason, we refrain from providing a uniform typology here, and instead refer readers to country-specific sources with classifications for Brazil [67], China [63, 65, 66, 103, 118, 119], Ethiopia [120-122], India [123], Kenya [90, 123, 124], Mexico [69, 70], Turkey [108], Uganda [92, 125, 126], and Vietnam [76, 127, 128].

In any case, most live animals or meat production in a given sector in the countries we researched can still be attributed to smaller-scale operations [76, 92, 100, 120-122, 124-126, 128-132]. However, the role of larger-scale operations is expanding [86, 103, 113, 126, 131-137]. In China, for example, large-scale pig farms raising 3,000 to 50,000 pigs per year were responsible for $16 \%$ of the country's pigs by 2010, while medium-scale and small-scale farms raised $48 \%$ and 34\%, respectively [103]. In Vietnam, intensification and scaling up are reflected in the declining percentage of pigs raised on farms with no more than ten pigs-from 80\% in 1999 to $64 \%$ in 2006 [131].

In addition, larger-scale or more intensive operations tend to be found in specific geographic areas of a given country. In Ethiopia, poultry farms with capacity for 10,000 birds have been established in urban areas around and east of the country's capital, and account for one to two percentage points of national production $[120,122,129]$. Similarly, more intensive meat production is based in urban and peri-urban areas in Uganda, while extensive systems of subsistence-based production continue to be more prevalent in that country's arid and semi-arid regions [138]. In Vietnam, poultry production is well developed everywhere, but is especially 
concentrated in urban areas and the Red River and Mekong River deltas [128, 130, 139].

\section{Concentration}

Source documents described some tendency toward concentration of food animal production or related sectors (such as feed or meat processing) in several countries studied $[66,70,90,92,118,119,124,125,140$ 148]. The scope of this study did not include mapping corporate structure or subsidiary relationships. Nevertheless, it does appear that IFAP expansion has been fueled by a mix of entities, including US-based corporations and foreign-based corporations that have adopted a production model similar to that of their US counterparts. Some of these foreign entities operate in multiple countries, while others are focused in a specific LMIC. In Brazil's Southern Region, which started experiencing industrialization of the pork and poultry industries several decades ago, the number of large-scale broiler farms increased by $67 \%$ between 1974 and 1992, while the number of broiler farms overall decreased by $24 \%$ [143]. In China, consolidation of the pig sector has resulted in family farmers choosing between exiting the sector, becoming specialized hog producers, or working as waged, migrant laborers [66]. In Mexico, one source described the poultry sector as exhibiting more concentration than the United States, with three producers accounting for $60 \%$ of the market by 2005 [72]. According to another source, structural readjustment imposed by the International Monetary Fund (IMF) and economic liberalization coincided with $27 \%$ of poultry producers leaving the business between 1980 and 1990 [70].

The poultry sector is also where concentration is most evident in Turkey, and most production is attributed to integrated enterprises using contract farming [141, 149]. By the mid-2000s, the top 20 and top five of 66 integrated broiler companies accounted for $84 \%$ and $47 \%$ of the market share, respectively [145]. Researchers have described this level of concentration as dampening competition, and rendering the broiler sector a loose oligopoly [141].

Concentration has also been documented in related sectors, such as animal feed and meat processing. In the Brazilian state of Rio Grande do Sul, the top five pork and poultry processing companies controlled $63 \%$ and $85 \%$ of their respective markets in 2009 [142]. The Kenyan vertical integrator, Farmer's Choice, is characterized by the FAO as having a monopoly on pork processing, handling $80 \%$ of the pigs processed in the country [90], while one Ugandan company is reportedly responsible for $85 \%$ of Kampala's processed meat market and holds a monopoly over beef processing [125]. In Vietnam, a news source reported that Masan Group is undertaking acquisitions and expansion, with the goal of attaining $50 \%$ of the country's feed market by 2020 [148].

\section{Vertical integration}

In a few of the countries studied, sources documented a substantial amount of vertically integrated production and processing, and the presence of large integrating firms [66, 69, 70, 84, 100, 127, 130, 145, 150-153]. In Brazil, over 90\% of poultry production occurred within vertically integrated systems by 2012 [154]. In China, at least $70 \%$ of pork and poultry production and $80 \%$ of aquaculture production operate through the most highly integrated and governmentendorsed form of vertical integration, in which integrating companies are designated officially as "dragonhead enterprises" and receive special benefits [151]. Vertical integration has been described as increasing across Asia [155], with much of the poultry in India and Vietnam now being raised by contract farmers producing for vertical integrators $[134,153,156]$.

In other countries, such as Ethiopia and Kenya, the extent of vertical integration has been much less, with at most one or two companies in each livestock sector operating as integrators [87, 106, 124, 157]. Despite the small number of integrators, integrated production appears to be on the rise in the Kenyan poultry sector [90], while official and non-governmental sources in Ethiopia are arguing for increasing vertical linkages and supply chain development $[86,129,158,159]$.

Sources for some countries, such as Brazil, Mexico and Turkey, noted that producers seeking to continue production independently have been unable to compete with vertically integrated producers, who can source inputs from integrators, reduce their transaction costs, and reap economies of scale [67, 72, 141, 160]. A few studies have found that integrated farmers sometimes face lower profit margins or inequitable contracts [142, $153,160,161]$.

\section{Feed}

Feed is one of the costliest inputs to food animal production, and has been identified as one of the most important determinants behind the expansion of IFAP [67, 84, 162165]. For many countries, the scarcity of feed and resources for producing feed has impeded IFAP expansion. In China, feed production has grown to become a multibillion-dollar industry [166], but there remains a shortage of water, land, and labor, to produce sufficient feed grains domestically, such as corn and soy [167]. Intensification of animal agriculture in China is exacerbating the feed shortage [114], as well as incentivizing cultivation practices like high-density planting, monoculture growing, and mechanization [167]. Within Brazil, certain regions are able to produce large quantities of corn and soy, and these crops are transported over long distances to regions 
where animal production is concentrated [168]. The cattle sector in Mexico has coped with a lack of grazing land and feed resources by exporting live cattle to be finished elsewhere [169]. Turkey and Vietnam have increased industrial feed production, but they rely heavily on feed crop imports [74, 100, 165, 170]. Vietnam spent an estimated 4.5 billion USD on imports of feed materials (mostly corn and soybean) in 2014 [171]. Foreign feed companies have a dominant role in Vietnam's feed production [100, 172], and some of these companies work with integrated farms that raise animals intensively [152]. Meanwhile, in Uganda, feed produced domestically is reported to be very poor quality. Problems include low nutrient content, mixing with non-feed materials to increase the weight of the feed, feeds that have been moistened, and feeds containing toxins harmful to humans (as well as animals), such as aflatoxin $[173,174]$. In contrast to these countries, Myanmar is described as being self-sufficient in livestock feed thus far, though it does import feed supplements and additives [83].

One specific issue noted in Ethiopia, India, and Kenya pertains to the opportunity cost of using scarce resources to produce grains for animal feed, in a context of food insecurity: such resources can be used more efficiently to produce crops directly consumed by humans [88, 124, 164, 175-177]. In Ethiopia, the government aims to increase annual domestic feed production from 5 million $\mathrm{kg}$ in the early 2010 s to 14.5 million $\mathrm{kg}$ by 2025 [178]. Currently, most grain produced in the country is used to feed humans, and one NGO has warned that using domestically-produced grain to feed livestock animals rather than humans may threaten food security in Ethiopia, especially if these animals are subsequently exported [175]. Expanding grain production is a challenge, given the scarcity of arable land and problems with over-grazing and degraded pastures [179].

\section{Antimicrobials and other growth-promoting compounds}

In most of the studied countries, there is indication that antimicrobials and other growth-promoting compounds are being used in livestock production with inadequate veterinary oversight. Notable examples include China, where a large, uncertain quantity of such additives is used for both prophylactic and growth promoting purposes $[105,115$, 180-187], and India, where non-therapeutic usage of antibiotics by the poultry industry has become such a problem that the Indian Medical Association has demanded measures to prevent medically important antibiotics from being used [188]. Other examples are described in Ethiopia [175, 189, 190], Kenya [88, 106], Mexico [169, 191], Myanmar [83, 98], Uganda [192-196], and Vietnam [99, 101, 197]. The extent of the problem and information available varies by country and sector, and generally more problems have been documented in the pig and poultry sectors.
Across studies and countries, information about the use of antimicrobials and other growth promoting compounds was presented inconsistently, precluding quantitative estimation of use. By antimicrobial class, we found most frequent mention of tetracyclines (in five countries), followed by aminoglycosides, beta-lactams and macrolides, each in three countries. Arsenicals, fluoroquinolones, ionophores, penicillins, polymixins (colistin), polypeptides, and sulfonamides were mentioned as being used in two or fewer countries. We also found mention of beta-agonists ractopamine (in China) and clenbuterol (in China and Mexico). By species, mention of antimicrobial use was most common in chicken production (six countries), followed by swine (four countries) and cattle (three countries).

\section{Animal welfare (housing facilities)}

Information was limited on the welfare of livestock animals, especially regarding the physical conditions in which they are raised. Sources for a few countries noted the level of confinement and density of livestock housing. For example, in Brazil, poultry are reportedly raised in a high degree of confinement [154], at an average density of $34 \mathrm{~kg}$ per square meter, according to an industry report [198]. Animals in China, especially poultry and swine, are also raised in extremely confined and densely crowded conditions [119, 187, 199]. Even small- and medium-sized chicken farms located in the more remote parts of the country stock birds at a high density, and use antibiotics as inputs to counter their reduced immunity $[119,187]$. One study in Ethiopia documented a density of 13 birds per square meter for a 10,000-broiler farm, which was described as having poor biosecurity and hygiene practices [200], while another source noted that overcrowding prevented animals from expressing their natural behaviors in cattle feedlots and confined dairy cow facilities, as well as caged poultry systems [175]. In India, poultry cages added to farms after 2012 were required to be a minimum of 750 square centimeters, a $50 \%$ increase from the prior standard [201]; however, a 2008 source noted that most of the country's poultry flock was raised in open houses, and only in winter in a few regions were birds housed indoors in heated shelters [202].

International animal welfare NGOs have noted concerns in Brazil's swine farms, such as the use of gestation crates, mutilations, very early weaning age, limited bedding, close confinement of sows, and insufficient climate control for young piglets [203, 204]. Researchers described a lack of regulations on broiler and swine housing conditions, such as no norms on ammonia concentrations, temperatures, heat stress risk, and noise level exposure [198]. In China, non-governmental organizations have also documented the common use of gestation crates for swine and battery cages for layers and broilers, with both practices being 
perceived as Western and 'scientific' [95, 187]. Ventilation, especially in broiler farms and beef cattle sheds, is poor, while floors tend to be made of hard concrete, causing lameness in cattle and preventing pigs from rooting [187].

\section{Slaughtering and processing infrastructure}

Slaughtering and processing capacities vary greatly across the ten selected countries. In some cases, there has been an expansion of infrastructure apace with or even outstripping the supply of live animals, while in other countries, slaughtering and processing are undertaken mostly by small- and medium-scale operators with poor hygiene and outdated facilities. In the Chinese pork and beef sectors, processing capacity has exceeded the supply of live animals $[65,205]$. Modernized slaughterhouses receiving preferential treatment from the government in the form of tax breaks, low-interest loans, and other assistance have operated below capacity [65]. In Mexico, the number of federally-inspected plants, considered the most sophisticated slaughterhouses, more than quadrupled between 1999 and 2005, but operated at 55 to $60 \%$ capacity as of 2000 [69]. Similarly, one source described Uganda's slaughtering facilities as operating at $50 \%$ capacity due to the lack of live animals [125]. At the same time, the three main slaughterhouses serving Kampala are considered overburdened, and meat-processing has been essentially monopolized by one integrating firm controlling $85 \%$ of the capital's processed meat market [125].

Sources in several other countries also highlighted inadequate infrastructure. For example, in India, processing was described as unhygienic [206], and a top priority of the government's Five-Year Plan from 2012 to 2017 was to upgrade the country's registered meat-processing plants and export-oriented slaughterhouses [164]. In Kenya, a 2014 report noted that $30 \%$ of broilers were slaughtered in large- or medium-scale slaughterhouses; the rest were slaughtered in rudimentary, on-farm facilities [90]. As for swine, one integrator dominated the landscape, with a factory that slaughtered 400 pigs daily as of 2012; in contrast, the other three main slaughterhouses in Kenya slaughtered only 15 to 50 pigs daily [90]. In the Vietnamese swine sector, a 2008 survey revealed that of 434 slaughterhouses, only $45 \%$ had licenses to operate, $35 \%$ had sanitary facilities, and $25 \%$ had running water [100].

Overall, however, it appears that many countries have at least some industrial-scale facilities with 'modern' equipment and high throughput, as well as plans to build more of these facilities [65, 69, 76, 84, 100, 139, 207-209]. For example, alongside backyard slaughtering and thousands of slaughter points (facilities with very small daily slaughtering capacities), Vietnam has 35 industrial-scale slaughterhouses, most of which are located in the Red River Delta [76], and the government is actively promoting the expansion and upgrading of slaughterhouses [100].

\section{Land use}

In a few of the countries studied, food animal production has triggered controversies over land use, given the limited arable land available in certain countries. In Ethiopia, rural communities in the Gambela region and Lower Omo Valley have denounced "land-grabbing" and displacement by investors, including multinational corporations, who are establishing industrialized agricultural enterprises in the region [210]. The amount of land in the country is said to be insufficient for sustaining current levels of food animal production, let alone increases in production [175]. In Uganda, the government itself has warned that increasing livestock numbers will put greater pressure on rangelands and water resources [91]. The Chinese government has urged companies, especially large-scale DHEs, to invest in overseas land and feed deals as part of the country's overall strategy to expand livestock production [151]. Feed destined for China has been sourced from Africa, Eastern Europe, Southeast Asia, and Latin America [167]. Chinese companies have established soybean contract farming in Brazil [211], and various other land acquisition deals for soy production are also in development in Argentina [167].

Land scarcity has been used as a justification for more intensive food animal production practices. The swine sector in China is said to focus increasingly on landless industrial systems that source feed externally and do not have any land for manure disposal (manure is rarely recycled given the lack of surrounding land) [103]. CAFOs have been portrayed as the only way to support rising demand for meat, given the country's limited land base [151]. In Uganda, a government document pointed to free-range extensive production systems as an inefficient use of land and a source of resource management conflicts in the Albertine Rift region [212]; others have suggested intensifying production and adopting zero-grazing systems in overstocked areas [213]. There are also proponents of zero-grazing systems in Ethiopia, who argue that confining animals in feedlots can prevent over-grazing and environmental degradation [213]. A similar argument-that intensification can help reduce deforestation-has also been presented in Brazil, and the issue has received significant attention because of the public sentiment against conversion of the Brazilian Amazon into cattle ranches. Various sources in Brazil, including ones tied to the government, have attempted to show that the increase in cattle production is due to intensification, rather than deforestation and expansion of pastures [214-220]. However, there has been some recognition that intensification 
may lead to more deforestation over the long run, if the sector appears more attractive [61].

\section{Waste management}

For various countries, like Brazil [221], China [222], and Vietnam [223], the amount of manure and wastewater generated by food animal production is an environmental and public health concern because the sheer volume of waste is difficult to manage. An estimated 1.9 billion tons and 227 million tons of manure excretion and pollution, respectively, resulted from all livestock production in China in 2010, corresponding to 1.86 tons of livestock manure pollution per hectare of arable land in the country [222]. Under the scenario of business as usual, total livestock manure pollution is projected to increase $31 \%$ to 298 million tons by 2020 [222]. Swine waste, in particular, accounts for $47 \%$ of total livestock waste generated in China [85].

Sources referred to waste management practices in varying detail. Some sources described practices for treating or disposing of animal waste, but this information may not have been exhaustive, and it is not always known how widely certain methods are practiced. Although incomplete, the general picture emerging from various countries is that waste is not being adequately treated prior to discharge $[83,87,90,100,103,104$, 108-110, 124, 135, 180, 224, 225].

Specific practices in Brazil include storage of waste in uncovered, open slurry tanks [168] and application of liquid manure to land [102, 168, 221]. In China, animal waste from large-scale facilities is separated into solid parts-which are dried and sold as fertilizer or used as compost-and liquid parts-which are occasionally stored in open-air lagoons or diluted with large quantities of water to be used for irrigation [104]. A couple sources noted issues with liquid manure spilling or leaching into surrounding soil, rivers, and other water bodies [103, 180]. Although some large swine farms have received subsidies from the government to build biogas tanks to manage waste, distribution and utilization of huge volumes of biogas slurry and residue persist as challenges [85]. In Vietnam, waste is also separated into solid and liquid parts, followed by composting of solid parts and discharge of liquid parts into crop fields and surface water, with little pretreatment $[82,225]$. Even in industrial-scale facilities, there has been a lack of waste treatment capacity and awareness of laws on managing waste [83].

In countries with relatively less intensive production, lower livestock numbers, and hence smaller volumes of waste, waste management is still problematic. In Kenya, manure disposal has been identified by the FAO as a major challenge for commercial pig farms that are not integrated with crop production, as some of these farms dump manure onto the roadside, on uncultivated land, or into sewage and storm water drains, causing both air and water pollution [124]. Poultry farms, on the other hand, sell manure without first composing it, and this may be a source of disease for other farms where the manure is applied to the land [87]. In Turkey, cattle-fattening enterprises reportedly dump manure onto unoccupied areas [108], or apply it as fertilizer without any treatment [109]. Most farms store waste in open areas by villages or barns for months at a time, or sometimes even indefinitely [109, 110]. Although a few cattle farms have a manure storage hole, the holes may be poorly built [109].

Inadequate or patchy regulation of animal manure management and disposal of dead animals was noted in Brazil [67, 102]. In Mexico, one 2010 source indicated that swine CAFOs in one area have opted to pay fines rather than invest in expensive wastewater treatment infrastructure [226]. A study of 135 cattle farms in western Turkey revealed that most farms have ignored regulations that limit the storage of animal waste to three months, with up to half storing waste for six to eight months [109]. Further, regulations on the distance required between water resources and waste storage facilities were not being followed [110].

\section{International trade as related to LMICs}

International trade considerations are important for a few of the countries studied, but in rather different ways. For example, China meets its growing demand for animal feed not only by importing feed crops, such as whole soybeans [166], but also by investing in contract farming abroad [211]. There are also reports that China is sourcing or intends to source live animals from Australia and Mongolia [227, 228]. Brazil, on the other hand, is an exporter of beef, and its trade relationships have been influential in production practices within the country. For example, it has committed to not using growth promoters in animal products exported to Russia $[229,230]$, and concerns about the use of ractopamine has resulted in Russia banning Brazilian pork and beef imports at various times [229-231]. Similarly, Canada banned meat from two poultry plants in Brazil for several years when it detected antibiotic residues [232]. Brazilian meatpacking companies have also responded to pressure from the EU market to regulate the use of antibiotics, given the importance of that market for Brazilian exports [233].

Mexico's defining trade relationship is with the United States, due to geographic proximity and the North American Free Trade Agreement (NAFTA), which is said to have driven the industrialization of the country's livestock sector [234]. Following NAFTA, multinational agribusinesses acquired a dominant role in Mexico, obtaining competitive advantages over domestic companies because they could obtain large volumes of feed much 
cheaper in the United States and could import them tariff-free [70, 234].

Ethiopia faces yet a different problem, with illegal cross-border trade in cattle assuming a significant role: an estimated 320,000 heads of cattle are exported illegally each year (a figure from the mid-2000s) [235]. This activity, typically undertaken by small-scale traders, reportedly hinders beef cattle production and value chains by creating a shortage of live animals and processed meat for legal export [235].

\section{IFAP impacts and lack of impact studies}

Overall, the impacts of industrialized food animal production in the selected LMICs have not been thoroughly examined. There are several domains of concern, including occupational health, environmental health, and other socio-economic and community impacts. However, most sources mentioned these concerns in a general way; in the peer-reviewed literature, there have been relatively few primary research studies investigating a given issue or site.

There is variation by country and topic regarding the extent to which impacts have been studied or even mentioned. For example, our search methodology yielded little research and attention regarding worker health across all of the countries. As for environmental and public health, concerns about impacts caused by industrialized food animal production were noted in many of the countries studied, and a few countries even had primary research on these issues.

Reports from Vietnam, for instance, flagged concerns about antibiotic resistance associated with the use of commercial poultry feed [236], bad odors and increased zoonotic disease risk caused by industrial livestock farms near urban areas [128], reduced biodiversity due to extinction of indigenous breeds [237], atmospheric pollution and water depletion caused by the industrialization of livestock production [76], contamination of surface and groundwater from concentrated swine production [131], and generation of more animal waste than could be recycled naturally due to expanded livestock production, with associated threats to soil, water, and air quality, as well as public health [76].

In Brazil, several studies noted that intensified cattle ranching has attracted more producers into the market and fueled deforestation, overgrazing, greenhouse gas emission, and use of herbicides, fungicides, and insecticides [61, 217, 220, 235]. However, it was also claimed that methane emissions per unit product has decreased, deemed a sign of greater efficiency [217, 220, 235]. Comparative assessments noted that industrial systems in Brazil rely on feed with a larger water footprint [238], and linked the production of animal feed for intensive livestock farming to greenhouse gas emissions, loss of biodiversity, freshwater eutrophication, marine eutrophication, and terrestrial acidification, among other impacts [168].

In Mexico, there have been resident reports of respiratory health issues due to hog pollution in the Perote Valley area [226], and governmental investigations found decreased aquifer levels, increased odors, and poor air quality due to swine farms in that region [224]. Meanwhile, another study documented a high concentration of antibiotic-resistant pathogens near an urban-based industrial dairy operation in northern Mexico [107].

In Turkey, sources alluded to water and air pollution from industrial scale animal farming [108] and the livestock sector's significant contributions to methane emissions [239]. One study found that cattle breeding operations in one region were inadequately handling animal waste, leading to odors, flies, and contamination of soil and water resources [110].

There were also many sources on China, some involving empirical investigations and others consisting of secondary data. Specific concerns included infectious diseases due to inadequately treated animal waste [104, 240], drug resistance emerging from the overuse of antibiotics in animal production [93, 180, 182, 184, 186, 241], cancer risk deriving from trace metals, like arsenic, in manure [104, 240], severe food poisoning from the use of a steroid that promotes lean muscle growth [105], high levels of methane emissions from manure, which are more than any other country [242, 243], and pollution of surrounding land and water, with waste as a primary source of contamination $[104,151,166,240]$. According to one review article, larger farms cause more serious environmental contamination [115], and another report noted that methane emissions from industrial farms are higher due to the manner in which waste is stored and handled [242]. However, within policy circles in China, many argue that industrialization of livestock production is beneficial for the environment because more concentrated waste management will lead to more precise techniques being used, greater investment in facilities, and easier monitoring [244].

Two studies sought to characterize drug resistance in pathogens isolated from livestock fecal samples in Uganda. One looked across chickens, cattle, swine, and small ruminants [192], and the other, focused on broiler farms with greater than 100 chickens [194]; both found multidrug resistance in most isolates obtained. Another source mentioned the pressure of increasing livestock numbers in the country on rangelands and water systems [91].

We found less information about environmental and public health impacts in the other countries studied. There were brief references to concerns about contamination from waste and decomposing carcasses in India [67], disease transmission risk from poultry manure [87] and water and air pollution from swine manure in Kenya [124]. 
Finally, socioeconomic impacts due to industrialization of the livestock sector have also been examined by sources from several countries. The disparity between larger-scale producers and smaller-scale producers has been a particular concern, especially when the latter can no longer remain competitive. For example, research in Brazil documented that larger-scale swine and broiler producers cause more environmental harm than smaller-scale counterparts, but smaller farms internalize environmental costs more than larger ones [67]. In Vietnam, a 2003 study cited increased unemployment and impoverishment due to smaller producers leaving the sector and fewer rural employment opportunities as possible negative effects of intensified production [237]. Sources in China noted that in the context of agricultural industrialization, smallholders are losing their livelihood, inequality is increasing, and rural-to-urban migration is on the rise [166]. The pork industry's consolidation has caused small-scale farmers to choose between becoming specialized producers or waged migrant workers [66]. Similarly, in Turkey, researchers have argued that governmental initiatives promoting the expansion of the livestock sector have been harmful to smallholder producers, who have been unable to stay competitive in the new policy and economic environment $[73,245]$.

With vertical integration a key feature of industrialization, several studies have examined whether contract farming can be a mechanism for small-scale producers to maintain their livelihoods. An investigation of poultry farming in one county of Kenya showed that contract farming was associated with a significant, positive gain in net revenue per bird, among a sample of 180 small-scale poultry farms [246]. In India, however, a 2007 report reviewing the literature on the impact of contract farming on smallholders concluded that contract farming could help them stay in business, but that there was conflicting data on whether contract or non-contract farming was more profitable for farmers and limited evidence showing that vertical coordination could reduce risk and transaction costs for small farmers [202]. A subsequent study on integrated broiler production in India found that small-scale farmers tended to be excluded, contract farmers perceived contract terms to be unfair, and contract farmers ultimately reverted back to being independent producers after obtaining experience and achieving a certain scale of production [153].

\section{Discussion}

The sources we reviewed indicate increased uptake of the IFAP model in the selected LMICs regarding size of operations, corporate consolidation, and vertical integration. These trends vary by species and geography, though IFAP is not the dominant production model in many of the countries. Smaller and independent producers in some regions have either exited the sector or specialized and expanded in size, in a context of shifts to larger operations, more control by fewer companies, and use of contract growers. In addition, corporate consolidation is seen in feed and meat processing, so small and/or independent businesses at multiple stages of the supply chain may be impacted. Uncertainty remains regarding the costs and benefits of losing independent actors in the supply chain, and whether these changes improve producers' livelihoods and in-country development goals more broadly. An important consideration is the availability of alternative livelihoods for small and independent animal and feed producers and processors, especially if there is a large number leaving the sector in one region.

\section{Domestic policies}

Many of the examined countries have explicit plans to industrialize, while others (such as the African countries studied) are more focused on improving the livelihoods of small-scale farmers. In countries seeking to industrialize food animal production, governments have instituted policies favoring large operations that use certain production methods, and increased centralized capacity in related sectors like slaughtering and meat processing. Many of the LMICs studied currently have a combination of smaller, older slaughterhouses and processing facilities and large, newer facilities that might operate at half capacity because the domestic supply of animals does not match the size of the facilities. Our review found that governments often play key roles in supporting and promoting new processing facilities in pursuit of the IFAP model.

\section{Access to land and feed}

Animal production is resource-intensive compared to production of plant-based foods, in large part due to the land required to feed animals [247]. While animals and their feed are co-located in grazing systems, industrially- produced animals can be separated from where feed crops are grown. This separation between confined animals and feed cropland has led to promotion of IFAP as an efficient way to produce animal products compared to extensive/ grazing systems, especially where land is scarce. Land is required to produce feed crops, however, and some countries and corporations are establishing relationships abroad to ensure land is available to produce feed for domestic animal production. Among other potential negative impacts, global expansion of land used to produce animal feed can lead to deforestation, which threatens biodiversity and contributes to global climate change [248, 249].

Access to feed inputs has been a significant impediment to industrialization in certain countries, stemming from a lack of resources to produce feed within those countries and/or an inability to import feed. Where feed is produced domestically, quality concerns have been documented. If 
there is a significant increase in global feed production, it is possible that industrialization will occur more rapidly as that barrier is removed. There is evidence of concern in some countries that meeting demand for feed through domestic production will threaten food security because less grain will be available for direct human consumption. It is unclear whether there are safeguards in any countries to control the competition for resources between human food and animal feed.

\section{Global trade}

As industrialization of the food animal sector progresses in the studied countries, our review suggests that trade will play an increasingly important role for these countries in the context of our globalized food system. In particular, trading of feed inputs [250] and animal stock [251], as well as the leasing and foreign ownership of land [252], all connect domestic food production to other parts of the globe. This trading acquires heightened importance considering the natural resource scarcities observed in various LMICs studied. In some cases, existing international trade agreements may facilitate exchange of inputs and export of finished products across adjacent borders. Additionally, food safety considerations of high-income countries related to the use of pharmaceuticals in animal production [253] may erect short-term trade barriers for countries' export markets, which may ultimately influence future usage patterns of these compounds (as observed in Brazil's trading relationships with Russia and Canada).

\section{Dietary patterns and resource use}

As noted previously, consumption of animal-based foods in LMICs, especially among the most food-insecure, could have a positive impact on undernutrition and its impacts. The issue at stake, however, is how to increase availability of and access to the appropriate animal- source foods sustainably and without creating new public health threats. Though not the focus of this paper, an additional concern is the disease risk associated with over-consumption of animal-based and processed foods, as populations of LMICs adopt a more "western-style" diet [254].

An important concept related to feeding a growing and more affluent global population in the coming years is sustainable intensification (SI), which refers to producing more food while reducing use of resources and limiting environmental impacts [49]. A major focus of SI, although no specific agreed-upon definition exists, is increasing crop yields on underperforming fields, or closing yield gaps. There are many points of contention among various food system and agricultural experts over whether the focus should be on increasing crop yields given potential negative externalities (e.g., increasing use and runoff of commercial fertilizers, and better yields with no rise or a reduction in farmers' incomes due to costs of inputs) [255]. Regarding production of animal protein, some see the promise of SI as facilitating increased feed production without using more arable land by closing yield gaps, but rapid growth in demand for feed could eclipse yield gains and fail to reduce overall land and water use. If strategies incorporating SI into IFAP are too narrowly focused, efforts by private and public stakeholders to address the serious environmental and public health impacts associated with expansion of IFAP will not be successful.

\section{Infrastructure and regulations for protection of environmental health}

There is a nascent, yet compelling, body of scientific literature on the impacts of IFAP in some of the studied countries, which reinforces concerns regarding negative environmental and public health externalities, especially when IFAP operations are located close to urban/peri-urban and other populated areas. This is consistent with research demonstrating similar problems in high- income countries, even in the face of arguably more regulations and monitoring infrastructure [8]. Moreover, although there are gaps in the information we could find for specific countries and certain topics, such as occupational health, there has been evidence of these and other impacts in the United States. We did not find evidence that these circumstances would be meaningfully different in LMICs. As regulatory frameworks, monitoring and enforcement capacity, and technical expertise (e.g., in veterinary health) are less developed in LMICs, there is reason to believe that impacts would be worse overall-a hypothesis that underscores the need for research and policy attention to IFAP issues in LMICs.

For example, our literature review did not identify stringent regulations concerning control of pharmaceutical agents and delivery of veterinary medical services in the context of IFAP. There is fierce debate over the effectiveness of these regulatory measures on antimicrobial resistance in high income countries [253]. Despite this, weak veterinary infrastructures and ready access to these drugs were repeatedly mentioned as concerns in the studied countries and have been identified as public health concerns in the literature [256]. Similarly, regulation of waste management is especially critical in countries that currently have established IFAP due to the volume of excrement and mortalities requiring disposal. In the LMICs studied, while some animal waste is used on fields as fertilizer, there are issues due to a lack of waste storage infrastructure required to properly compost wastes before use, indiscriminate disposal in places with potential public contact, and noncompliance where regulations do exist. It is uncertain how broadly these poor waste management practices apply to sectors in each country. On the issue of occupational health, the 
lack of information on worker well-being in our selected LMICs likely reflects the challenges of underreporting and conducting research with these hard-to-reach study populations (e.g., migrant or undocumented workers, job-insecure and economically vulnerable laborers). The challenges, documented elsewhere [257-261], are likely exacerbated in low-resource settings.

\section{Animal welfare}

Lastly, in addition to environmental and public health impacts, industrialization of food animal production in LMICs may have important implications for animal welfare globally. Regulatory protections for animal welfare have been described as weak in the United States [18]. Similarly, we did not find evidence of comprehensive regulatory protection of animal welfare in the examined countries. Though availability of information on the conditions in which animals are kept was limited, it appears that in LMICs where IFAP has developed, animal housing conditions are similar to those of industrial operations in the U.S. and other high-income countries, especially regarding density. Research has highlighted the interconnections between compromised animal welfare and public health concerns. For example, increased stocking density has been demonstrated to contribute to the transmission of pathogens among animals, to workers and into surrounding communities [7, 38, 262]. Moreover, animals confined in crowded conditions are not able to express natural behaviors [19], which can lead to stress and poor animal health. Civil society campaigns based on examinations of animal welfare within IFAP operations have been successful at incrementally improving conditions in some high-income countries (e.g. [204]). It is unclear whether similar efforts would be effective in the LMICs we examined.

\section{Limitations}

While our review of available peer-reviewed and gray literature yielded insights into the changing nature of food animal production in LMICs, it is important to acknowledge its limitations. We identified a disproportionate number of peer reviewed articles and other sources among countries. For example, the available literature concerning IFAP in China and Vietnam was quite substantial, while far fewer sources were available concerning production in Myanmar. While this may reflect a true differing degree of research and media coverage of animal production practices across countries, it may also be related to language barriers (our searches of the literature were limited to sources written in English, Portuguese, or Spanish). It is likely that as production expands in these countries, more information will become available regarding the factors evaluated in this manuscript. In the meantime, it would be a productive endeavor to examine native-language documents describing animal production in each of the countries included in our review, especially to have a fuller picture of domestic regulatory landscapes.

Moreover, given our objective of scoping an emerging situation, we were fairly inclusive in the types of sources relied upon, which extended beyond peer-reviewed scientific literature. The different types of "grey literature" sources used most certainly varied in quality. There was no formal method for assessing and weighing sources based on quality, which we recognize as a limitation of this study. Nevertheless, we hope our findings stimulate further researchparticularly research conducted by or with in-country partners-to elucidate the issues set forth here.

\section{Conclusion}

To our knowledge, this is the first systematic effort to assess IFAP trends through an environmental public health lens for a relatively large group of LMICs. We have identified existing or potential negative externalities of this mode of production in LMICs, as many of these impacts are foreshadowed by the experience of high- income countries where IFAP currently predominates. There is an urgent need for site-specific research to elucidate the impacts of IFAP on public health, the environment, the livelihoods of producers operating at varying scales, and animal welfare. This research agenda should also seek to identify case studies of successful, sustainable modes of food animal production in an LMIC, which could reveal lessons and best practices relevant for other producers, regions, and countries.

The question of whether IFAP growth facilitates food security globally or nationally also warrants special attention. For countries that are struggling with undernutrition and its severe, long-term impacts on health and well- being, we recognize that increasing availability of certain animalsource foods can be part of the solution and may alleviate national food insecurity. However, in addition to output metrics, the characteristics of production and distribution must also be considered. For example, how can increased availability of animal-source foods be best directed toward key vulnerable populations, such as children experiencing chronic malnutrition? Further, if increasing production does alleviate food insecurity, can such gains be sustained, given natural resource constraints? The relationship between increased IFAP and food security is complex, and will need to be investigated at the national, regional, and global scales.

From production to consumption of animal-source foods, the most appropriate strategies for change will likely vary across different places. In this vein, future assessments would benefit from the involvement of in-country partners. The findings from our mixed methods review contribute to the literature by outlining urgent collaborative research priorities aimed at informing national- and international-level decisions about the future of food animal production. 


\section{Acknowledgements}

The authors wish to acknowledge Martin Bloem for feedback on the manuscript, as well as Emily Hu and Brent Kim for research assistance.

\section{Funding}

YL, JF and KN were supported by a gift from the National Philanthropic Trust. JF and KN were also supported by the GRACE Communications Foundation (who did not provide funding specific to this project). The funders had no role in study design, data collection and analysis, decision to publish, or preparation of the manuscript.

\section{Availability of data and materials}

All data analyzed and referenced in this manuscript are publicly available, with hyperlinks provided in the references. They are also available upon request to the authors.

\section{Authors' contributions}

$\mathrm{YL}, \mathrm{JF}$ and $\mathrm{KN}$ contributed to the conception of this study and methodology used. YL, JF and KN drafted and revised sections of this manuscript. YL conducted data analysis. All authors read and approved the final manuscript.

\section{Ethics approval and consent to participate}

Not applicable

\section{Consent for publication}

Not applicable

\section{Competing interests}

The authors declare that they have no competing interests.

\section{Publisher's Note}

Springer Nature remains neutral with regard to jurisdictional claims in published maps and institutional affiliations.

\begin{abstract}
Author details
'Johns Hopkins Center for a Livable Future, Johns Hopkins Bloomberg School of Public Health, 111 Market Place, Suite 840, Baltimore, MD 21202, USA. ${ }^{2}$ Department of Environmental Health \& Engineering, Johns Hopkins Bloomberg School of Public Health, 615 N. Wolfe St., Baltimore, MD 21205, USA. ${ }^{3}$ Department of Health, Behavior and Society, Johns Hopkins Bloomberg School of Public Health, 624 N. Broadway, Baltimore, MD 21205, USA. ${ }^{4}$ Department of Health Policy and Management, Johns Hopkins Bloomberg School of Public Health, 624 N. Broadway, Baltimore, MD 21205, USA. ${ }^{5}$ Risk Sciences and Public Policy Institute, Johns Hopkins Bloomberg School of Public Health, 615 N. Wolfe St., W7007, Baltimore, MD 21205, USA.
\end{abstract}

Received: 9 January 2019 Accepted: 9 May 2019

Published online: 13 June 2019

\section{References}

1. Pew Commission on Industrial Farm Animal Production. Putting meat on the table: Industrial farm animal production in America: Johns Hopkins Bloomberg School of Public Health; 2008. https://www.pewtrusts.org/-/ media/legacy/uploadedfiles/phg/content_level_pages/reports/ pcifapfinalpdf.pdf. Accessed 21 May 2019.

2. Burton C, Martinez J. Contrasting the Management of Livestock Manures in Europe with the Practice in Asia: What Lessons Can Be Learnt? Outlook Agr. 2008:37(3):195-201.

3. Petersen SO, Sommer SG, Béline F, Burton C, Dach J, Dourmad JY, Leip A, Misselbrook T, Nicholson F, Poulsen HD, et al. Recycling of livestock manure in a whole-farm perspective. Livest Sci. 2007;112(3):180-91.

4. Heuer $H$, Schmitt $H$, Smalla K. Antibiotic resistance gene spread due to manure application on agricultural fields. Curr Opin Microbiol. 2011;14(3): 236-43.

5. Graham JP, Nachman KE. Managing waste from confined animal feeding operations in the United States: the need for sanitary reform. J Water Health. 2010:8(4):646-70.

6. Nigra AE, Nachman KE, Love DC, Grau-Perez M, Navas-Acien A. Poultry consumption and arsenic exposure in the US population. Environ Health Perspect. 2017;125(3):370.
7. Casey JA, Curriero FC, Cosgrove SE, Nachman KE, Schwartz BS. High-density livestock operations, crop field application of manure, and risk of communityassociated methicillin-resistant Staphylococcus aureus infection in Pennsylvania. JAMA Intern Med. 2013;173(21):1980-90.

8. Casey JA, Kim BF, Larsen J, Price LB, Nachman KE. Industrial food animal production and community health. Curr Environ Health Rep. 2015;2(3):259-71.

9. Donham KJ, Wing S, Osterberg D, Flora JL, Hodne C, Thu KM, Thorne PS. Community health and socioeconomic issues surrounding concentrated animal feeding operations. Environ Health Perspect. 2007;115(2):317.

10. Gilchrist MJ, Greko C, Wallinga DB, Beran GW, Riley DG, Thorne PS. The potential role of concentrated animal feeding operations in infectious disease epidemics and antibiotic resistance. Environ Health Perspect. 2007;115(2):313.

11. Heederik D, Sigsgaard T, Thorne PS, Kline JN, Avery R, Bønløkke JH, Chrischilles EA, Dosman JA, Duchaine C, Kirkhorn SR. Health effects of airborne exposures from concentrated animal feeding operations. Environ Health Perspect. 2007;115(2):298.

12. Pavilonis BT, Sanderson WT, Merchant JA. Relative exposure to swine animal feeding operations and childhood asthma prevalence in an agricultural cohort. Environ Res. 2013:122:74-80.

13. Schinasi L, Horton RA, Guidry VT, Wing S, Marshall SW, Morland KB. Air pollution, lung function, and physical symptoms in communities near concentrated swine feeding operations. Epidemiology. 2011;22(2):208-15.

14. Thu KM. Public health concerns for neighbors of large-scale swine production operations. J Agric Saf Health. 2002;8(2):185.

15. Wing S, Horton RA, Marshall SW, Thu K, Tajik M, Schinasi L, Schiffman SS. Air pollution and odor in communities near industrial swine operations. Environ Health Perspect. 2008;116(10):1362.

16. Nachman KE, Baron PA, Raber G, Francesconi KA, Navas-Acien A, Love DC Roxarsone, inorganic arsenic, and other arsenic species in chicken: a USbased market basket sample. Environ Health Perspect. 2013;121(7):818.

17. Nachman KE, Love DC, Baron PA, Nigra AE, Murko M, Raber G, Francesconi KA, Navas-Acien A. Nitarsone, inorganic arsenic, and other arsenic species in turkey meat: exposure and risk assessment based on a 2014 US market basket sample. Environ Health Perspect. 2017:125(3):363.

18. Kim BF, Laestadius LI, Lawrence RS, Martin RP, McKenzie SE, Nachman KE, Smith TJS, Truant P. Industrial Food Animal Production in America: Examining the Impact of the Pew Commission's Priority Recommendations. 2013. https://www.jhsph.edu/research/centers-and-institutes/johns-hopkinscenter-for-a-livable-future/_pdf/research/clf_reports/CLF-PEW-for\%20Web. pdf. Accessed 5 Jan 2019

19. Benson GJ, Rollin BE. The well-being of farm animals: Challenges and solutions: Wiley; 2008.

20. Clark B, Stewart GB, Panzone LA, Kyriazakis I, Frewer LJ. A Systematic Review of Public Attitudes, Perceptions and Behaviours Towards Production Diseases Associated with Farm Animal Welfare. J Agric Environ Ethics. 2016; 29(3):455-78.

21. D'Eath RB, Niemi JK, Vosough Ahmadi B, Rutherford KMD, Ison SH, Turner $\mathrm{SP}$, Anker HT, Jensen T, Busch ME, Jensen KK, et al. Why are most EU pigs tail docked? Economic and ethical analysis of four pig housing and management scenarios in the light of EU legislation and animal welfare outcomes. Animal. 2015:10(4):687-99.

22. von Keyserlingk MAG, Hötzel MJ. The Ticking Clock: Addressing Farm Animal Welfare in Emerging Countries. J. Agric. Environ. Ethics. 2015;28(1): 179-95.

23. Cole D, Todd L, Wing S. Concentrated swine feeding operations and public health: a review of occupational and community health effects. Environ Health Perspect. 2000;108(8):685-99.

24. Donham KJ, Cumro D, Reynolds S. Synergistic effects of dust and ammonia on the occupational health effects of poultry production workers. J Agromed. 2002:8(2):57-76.

25. Viegas S, Faísca VM, Dias H, Clérigo A, Carolino E, Viegas C. Occupational exposure to poultry dust and effects on the respiratory system in workers. J Toxicol Environ Health A. 2013;76(4-5):230-9.

26. Davidson ME, Schaeffer J, Clark ML, Magzamen S, Brooks EJ, Keefe TJ, Bradford M, Roman-Muniz N, Mehaffy J, Dooley G, et al. Personal exposure of dairy workers to dust, endotoxin, muramic acid, ergosterol, and ammonia on large-scale dairies in the high plains Western United States. J Occup Environ Hyg. 2018:15(3):182-93.

27. Radon K, Danuser B, Iversen M, Jörres R, Monso E, Opravil U, Weber C, Donham KJ, Nowak D. Respiratory symptoms in European animal farmers. Eur Respir J. 2001;17(4):747-54 
28. Hatcher SM, Rhodes SM, Stewart JR, Silbergeld E, Pisanic N, Larsen J, Jiang S, Krosche A, Hall D, Carroll KC. The prevalence of antibiotic-resistant Staphylococcus aureus nasal carriage among industrial hog operation workers, community residents, and children living in their households: North Carolina, USA. Environ Health Perspect. 2017;125(4):560.

29. Nadimpalli M, Rinsky JL, Wing S, Hall D, Stewart J, Larsen J, Nachman KE Love DC, Pierce E, Pisanic N. Persistence of livestock-associated antibioticresistant Staphylococcus aureus among industrial hog operation workers in North Carolina over 14 days. Occup Environ Med. 2015;72(2):90-9.

30. Nadimpalli M, Stewart JR, Pierce E, Pisanic N, Love DC, Hall D, Larsen J, Carroll KC, Tekle T, Perl TM. Livestock-Associated, Antibiotic-Resistant Staphylococcus aureus Nasal Carriage and Recent Skin and Soft Tissue Infection among Industrial Hog Operation Workers. PLoS One. 2016;11(11): e0165713.

31. Stewart-Johnson A, Dziva F, Abdela W, Rahaman S, Adesiyun A. Prevalence of methicillin-resistant Staphylococcus aureus (MRSA) in broilers and workers at 'pluck shops' in Trinidad. Trop Anim Health Prod. 2019;51(2):369-72.

32. Schaeffer JW, Reynolds S, Magzamen S, VanDyke A, Gottel NR, Gilbert JA, Owens SM, Hampton-Marcell JT, Volckens J. Size, composition, and source profiles of inhalable bioaerosols from Colorado dairies. Environ Sci Technol. 2017:51(11):6430-40.

33. Williams DAL, Breysse PN, McCormack MC, Diette GB, McKenzie S, Geyh AS. Airborne cow allergen, ammonia and particulate matter at homes vary with distance to industrial scale dairy operations: an exposure assessment. Environ Health. 2011:10(1):72.

34. Nachman KE, Graham JP, Price LB, Silbergeld EK. Arsenic: a roadblock to potential animal waste management solutions. Environ Health Perspect. 2005;113(9):1123.

35. Graham JP, Price LB, Evans SL, Graczyk TK, Silbergeld EK. Antibiotic resistant enterococci and staphylococci isolated from flies collected near confined poultry feeding operations. Sci Total Environ. 2009;407(8):2701-10.

36. Rule AM, Evans SL, Silbergeld EK. Food animal transport: A potential source of community exposures to health hazards from industrial farming (CAFOs). J Infect Public Health. 2008;1(1):33-9.

37. Poulsen MN, Pollak J, Sills DL, Casey JA, Nachman KE, Cosgrove SE, Stewart D, Schwartz BS. High-density poultry operations and community-acquired pneumonia in Pennsylvania. Environ Epidemiol. 2018;2(2):e013.

38. Poulsen MN, Pollak J, Sills DL, Casey JA, Rasmussen SG, Nachman KE, Cosgrove SE, Stewart D, Schwartz BS. Residential proximity to high-density poultry operations associated with campylobacteriosis and infectious diarrhea. Int J Hyg Environ Health. 2017;221(2):323-333.

39. Borlée F, Yzermans CJ, van Dijk CE, Heederik D, Smit LAM. Increased respiratory symptoms in COPD patients living in the vicinity of livestock farms. Eur Respir J. 2015;46(6):1605-14

40. Smit LAM, Hooiveld M, van der Sman-de Beer F, Opstal-van Winden AWJ, Beekhuizen J, Wouters IM, Yzermans CJ, Heederik D. Air pollution from livestock farms, and asthma, allergic rhinitis and COPD among neighbouring residents. Occup Environ Med. 2014;71(2):134-40.

41. van Dijk CE, Garcia-Aymerich J, Carsin A-E, Smit LAM, Borlée F, Heederik DJ, Donker GA, Yzermans CJ, Zock J-P. Risk of exacerbations in COPD and asthma patients living in the neighbourhood of livestock farms: Observational study using longitudinal data. Int J Hyg Environ Health. 2016; 219(3):278-87.

42. Casey JA, Shopsin B, Cosgrove SE, Nachman KE, Curriero FC, Rose HR, Schwartz BS. High-Density Livestock Production and Molecularly Characterized MRSA Infections in Pennsylvania. Environ Health Perspect. 2014;122(5):464-70.

43. Rasmussen SG, Casey JA, Bandeen-Roche K, Schwartz BS. Proximity to Industrial Food Animal Production and Asthma Exacerbations in Pennsylvania, 2005-2012. Int J Environ Res Public Health. 2017;14(4):362.

44. Steinfeld H, Gerber P, Wassenaar T, Castel V, de Haan C. Livestock's long shadow: environmental issues and options. 2006. http://www.fao.org/ docrep/010/a0701e/a0701e00.HTM. Accessed 5 Jan 2019.

45. Tilman D, Clark M. Global diets link environmental sustainability and human health. Nature. 2014;515(7528):518-22.

46. Gerber PJ, Steinfeld H, Henderson B, Mottet A, Opio C, Dijkman J, Falcucci A, Tempio G. Tackling climate change through livestock: a global assessment of emissions and mitigation opportunities. 2013. http://www.fao.org/3/a-i3437e.pdf. Accessed 5 Jan 2019.

47. Mekonnen MM, Hoekstra AY. A global assessment of the water footprint of farm animal products. Ecosystems. 2012;15(3):401-15.
48. Van Boeckel TP, Brower C, Gilbert M, Grenfell BT, Levin SA, Robinson TP, Teillant A, Laxminarayan R. Global trends in antimicrobial use in food animals. Proc. Natl. Acad. Sci. 2015;112(18):5649-54.

49. Tilman D, Balzer C, Hill J, Befort BL. Global food demand and the sustainable intensification of agriculture. Proc. Natl. Acad. Sci. 2011; 108(50):20260-4.

50. Development Initiatives. 2018 Global Nutrition Report: Shining a light to spur action on Nutrition. 2018. https://globalnutritionreport.org/documents/ 352/2018_Global_Nutrition_Report.pdf. Accessed 10 Dec 2018.

51. Dewey KG, Begum K. Long-term consequences of stunting in early life. Matern Child Nutr. 2011;7(s3):5-18.

52. Victora CG, Adair L, Fall C, Hallal PC, Martorell R, Richter L, Sachdev HS Maternal and child undernutrition: consequences for adult health and human capital. The Lancet. 2008;371(9609):340-57.

53. de Pee S, Bloem MW. Current and Potential Role of Specially Formulated Foods and Food Supplements for Preventing Malnutrition among 6- to 23Month-Old Children and for Treating Moderate Malnutrition among 6- to 59-Month-Old Children. Food Nutr Bull. 2009;30(3_suppl3):S434-63.

54. Dewey KG. Reducing stunting by improving maternal, infant and young child nutrition in regions such as South Asia: evidence, challenges and opportunities. Matern Child Nutr. 2016;12:27-38.

55. Thornton PK. Livestock production: recent trends, future prospects. Philos Trans R Soc B. 2010;365(1554):2853-67.

56. Kearney J. Food consumption trends and drivers. Philos Trans R Soc B. 2010; 365(1554):2793-807.

57. Golden MH. Evolution of nutritional management of acute malnutrition. Indian Pediatr. 2010;47(8):667-78.

58. Landrigan PJ, Fuller R, Acosta NJR, Adeyi O, Arnold R, Basu N, Baldé AB, Bertollini R, Bose-O'Reilly S, Boufford Jl, et al. The <em>Lancet</em> Commission on pollution and health. Lancet. 2018;391(10119):462-512.

59. Lam Y, Fry JP, Hu E, Kim BF, Nachman K. Industrial Food Animal Production in Low- and Middle-Income Countries: A Landscape Assessment. 2016. https://www.jhsph.edu/research/centers-and-institutes/johns-hopkins-centerfor-a-livable-future/research/clf_publications/pub_rep_desc/IFAP-lowmidincome-contries.html. Accessed 5 Jan 2019.

60. Grant MJ, Booth A. A typology of reviews: an analysis of 14 review types and associated methodologies. Health Inf. Libr. J. 2009;26(2):91-108.

61. Pacheco P, Poccard-Chapuis R. The Complex Evolution of Cattle Ranching Development Amid Market Integration and Policy Shifts in the Brazilian Amazon. Ann Assoc Am Geogr. 2012;102(6):1366-90.

62. Chen KZ, Wang J. Hog farming in transition: the case of China. International Food Policy Research Institute, Institute of Agricultural Economics and Development; 2012.

63. Cheng H, Wang Y, Meng Q, Guo J, Wang Y. Pork production system and its development in mainland China. Int J Fish Aquac. 2011;3(5):166-74.

64. Huang PC. China's new-age small farms and their vertical integration: agribusiness or co-ops? Mod China. 2011;37(2):107-34.

65. Waldron S, Brown C, Longworth J. A critique of high-value supply chains as a means of modernising agriculture in China: The case of the beef industry. Food Policy. 2010;35(5):479-87

66. Schneider M, Sharma S. China's Pork Miracle? Agribusiness and Development in China's Pork Industry. 2014. https://www.iatp.org/ documents/chinas-pork-miracle-agribusiness-and-development-chinas-porkindustry. Accessed 5 Jan 2019.

67. Delgado CLN, C. A.; Tiongco, M.; Barros, G. S. C.; Catelo, M. A. O.; Costales, A.; Mehta, R.; Naranong, V.; Poapongsakorn, N.; Sharma, V. P.; de Zen, S. Determinants and Implications of the Growing Scale of Livestock Farms in Four Fast-Growing Developing Countries. 2008. https://papers.ssrn.com/sol3/papers.cfm?abstract_id=1275538. Accessed 5 Jan 2019

68. Verma R. India subsidises broiler rearing. Global Meat News. http://www. globalmeatnews.com/Industry-Markets/India-subsidises-broiler-rearing. Accessed 5 Jan 2019.

69. Batres-Marquez SP, Clemens R, Jensen HH. The Changing Structure of Pork Trade, Production, and Processing in Mexico. Midwest Agribusiness Trade Research and Information Center, lowa State University,. 2006.

70. Martinez-Gomez F, Aboites-Manrique G, Constance DH. Neoliberal restructuring, neoregulation, and the Mexican poultry industry. Agr Hum Values. 2013;30(4):495-510.

71. Navarrete JDN, Santiago RT, Vite BF, Villagran BB, Herrera EO, Lopez JL. Impacts of technological level on production efficiency and economic 
variables in pork farms in the States of Guanajuato, Jalisco, Sonora and Yucatan, Mexico. Tec Pecu Mex. 2009;47(2):157-72.

72. Constance DH, Martinez F, Aboites G. Chapter 5 The globalization of the poultry industry: Tyson Foods and Pilgrim's Pride in Mexico. From Community to Consumption: New and Classical Themes in Rural Sociological Research. http://www.emeraldinsight.com/doi/abs/10. 1108/S1057-1922\%282010\%290000016008. Accessed 5 Jan 2019.

73. Aydin Z. Neo-Liberal Transformation of Turkish Agriculture. J Agrar Change. 2010;10(2):149-87.

74. United States Department of Agriculture. Turkey: 2010 Turkey Livestock Products Report. 2010. http://agriexchange.apeda.gov.in/ MarketReport/Reports/Turkey\%20live\%20stock\%20Report.pdf. Accessed 5 Jan 2019.

75. Yavuz F, Bilgic A, Terin M, Guler IO. Policy implications of trends in Turkey's meat sector with respect to 2023 vision. Meat Sci. 2013;95(4): 798-804.

76. Australian Center for International Agricultural Research. Improving the competitiveness of pig producers in an adjusting Vietnam market. 2011. https://cgspace.cgiar.org/bitstream/handle/10568/59784/ACIAR Policy_paper_CAP_Tuan.pdf?sequence=1. Accessed 5 Jan 2019.

77. Drucker $A G$, Bergeron $E$, Lemke $U$, Thuy LT, Zárate AV. Identification and quantification of subsidies relevant to the production of local and imported pig breeds in Vietnam. Trop Anim Health Prod. 2006; 38(4):305-22.

78. Food and Agriculture Organization of the United Nations. Livestock sector brief: Vietnam. 2005. http://www.fao.org/ag/againfo/resources/en/ publications/sector_briefs/Isb_VNM.pdf. Accessed 5 Jan 2019.

79. Hanh H, Roland-Holst D. The poultry sector in Viet Nam: prospects for smallholder producers in the aftermath of the HPAl crisis. Rome: Pro-Poor Livestock Policy Initiative Research Report, Food and Agriculture Organisation of the United Nations; 2007. https://assets.publishing.service. gov.uk/media/57a08bd6ed915d622c000f23/PPLPIrep-hpai_ vietnampoultryquality.pdf. Accessed 5 Jan 2019

80. Huong NT, Wayde J. Vietnam Livestock and Products Annual 2006. GAIN Report USDA Foreign Agricultural Service. 2006. https://apps.fas.usda.gov/ gainfiles/200609/146228906.pdf. Accessed 2 Jan 2019.

81. Lemke U, Mergenthaler M, Roßler R, Huyen L, Herold P, Kaufmann B, Zarate AV. Pig production in Vietnam--A review. Pig News Inf. 2008;29(2):1R.

82. Nga NTD, Ha NTT, Hai PG. Enhancing coordination in chicken production in Yen The district, Bac Giang province, Vietnam. J Int Soc Southeast Asian Agric Sci. 2011;17(2):104-16.

83. Food and Agriculture Organization of the United Nations. Swine Industry Profile of Selected South East Asian Countries; 2011.

84. United States Department of Agriculture. Turkey: Poultry Situation. 2010. https://webcache.googleusercontent.com/search?q=cache:fGK83aK56xkJ: https://gain.fas.usda.gov/Recent\%2520GAIN\%2520Publications/ Poultry\%2520update_Ankara_Turkey_1-29-2010.pdf+\&cd=1\&hl=en\&ct= clnk\&gl=us. Accessed 2 Jan 2019.

85. Tao HJ, Xie CP. A Case Study of Shuanghui International's Strategic Acquisition of Smithfield Foods. Int Food Agribus Man. 2015;18(1):145-66.

86. Addis Ababa Chamber of Commerce and Sectoral Associations. Livestock Resources: Potentials, Constraints, and Prospects for Private-Sector Development. 2006. http://docplayer.net/54636029-Addis-ababa-chamberof-commerce-and-sectoral-associations-livestock-resources-potentialsconstraints-and-prospects-for-private-sector-development.html. Accessed 5 Jan 2019.

87. Food and Agriculture Organization of the United Nations. Kenya Poultry Sector Country Review. 2008. http://www.fao.org/3/a-ai379e.pdf. Accessed 5 Jan 2019.

88. Kahi AK, Wasike CB, Rewe TO. Beef production in the arid and semi-arid lands of Kenya - Constraints and prospects for research and development. Outlook Agr. 2006;35(3):217-25.

89. Kakaire S. Will the new policy fix Uganda's agriculture? The Observer. 2014 http://www.observer.ug/features-sp-2084439083/57-feature/ 33814\%2D\%2Dwill-the-new-policy-fix-ugandas-agriculture. Accessed 10/15/ 15: 5 Jan 2019.

90. Bergevoet $R$, van Engelen A. The Kenyan meat sector: Opportunities for Dutch agribusiness. 2014. http://library.wur.nl/WebQuery/wurpubs/ 495738. Accessed 5 Jan 2019.

91. Republic of Uganda. Agriculture Sector Development Strategy and Investment Plan: 2010/11-2014/15. 2010. https://extranet.who.int/ nutrition/gina/sites/default/files/

UGA\%202010\%20Agriculture\%20Sector\%20

Development\%20Strategy\%20and\%20Investment\%20Plan.pdf. Accessed 5 Jan 2019.

92. Tatwangire A. Uganda smallholder pigs value chain development: Situation analysis and trends. 2014. https://cgspace.cgiar.org/bitstream/ handle/10568/34090/PR_UgandaSituationAnalysis.pdf?sequence. Accessed 5 Jan 2019.

93. Zhao L, Dong $\mathrm{YH}$, Wang $\mathrm{H}$. Residues of veterinary antibiotics in manures from feedlot livestock in eight provinces of China. Sci Total Environ. 2010; 408(5):1069-75.

94. Lockett $\mathrm{H}$. Antibiotics abuse makes China's pork industry a hotbed for drug-resistant bugs China Economic Review. 2015. http://www. chinaeconomicreview.com/growth-addiction. Accessed 5 Jan 2019:

95. Li PJ. Exponential Growth, Animal Welfare, Environmental and Food Safety Impact: The Case of China's Livestock Production. J Agric Environ Ethics. 2009;22(3):217-40.

96. Ministry of Agriculture, International Livestock Research Institute. Animal health strategy and vision for Ethiopia. Ethiopia Livestock Master Plan Background Paper. 2013. https://cgspace.cgiar.org/bitstream/handle/10568/ 67247/LMP_animalhealth_2013.pdf?sequence=1. Accessed 5 Jan 2019.

97. Verma R. Indian poultry farmers continue use of growth promoters, despite official ban. Global Meat News. 2014. http://www. globalmeatnews.com/Industry-Markets/Indian-poultry-farmers-continueuse-of-growth-promoters-despite-official-ban. Accessed 5 Jan 2019.

98. Sone P, Aung Y. Country Report Myanmar. Animal Production and Health Commision for Asia and the Pacific (APHCA) conference proceedings on Antimicrobial Use and Resistance in Livestock in the Asia-Pacific Region; 2012.

99. Kim DP, Saegerman C, Douny C, Dinh TV, Xuan BH, Vu BD, Hong NP, Scippo M-L. First survey on the use of antibiotics in pig and poultry production in the Red River Delta region of Vietnam. Food and Public Health. 2013;3(5):247-56.

100. Nga NTD, Ninh HN, Van Hung P, Lapar M. Smallholder pig value chain development in Vietnam: Situation analysis and trends. 2014. https:// cgspace.cgiar.org/handle/10568/53935. Accessed 5 Jan 2019.

101. Ton VD, Dang PK, Scippo M. Antibiotic Utilization in Pig and Chicken Production in Vietnam: Case Study in Red River Delta. In: International Conference on Hygiene and Importation Management of Livestock Products, The 14th AAA Animal Science Congress 2010. Pingtung: National Pingtung Unversity of Science and Technology; 2010.

102. Kunz A, Miele M, Steinmetz RL. Advanced swine manure treatment and utilization in Brazil. Bioresour Technol. 2009;100(22):5485-9.

103. Bai ZH, Ma L, Qin W, Chen Q, Oenema O, Zhang FS. Changes in Pig Production in China and Their Effects on Nitrogen and Phosphorus Use and Losses. Environ Sci Technol. 2014;48(21):12742-9.

104. Ju XT, Zhang FS, Bao XM, Romheld V, Roelcke M. Utilization and management of organic wastes in Chinese agriculture: Past, present and perspectives. Sci China Ser C. 2005:48:965-79.

105. Zhou GH, Zhang WG, Xu XL. China's meat industry revolution: Challenges and opportunities for the future. Meat Sci. 2012;92(3):188-96.

106. Omiti JMO, SO Okuthe. An Overview of the Poultry Sector and Status of Highly Pathogenic Avian Influenza (HPAl) in Kenya - Background Paper. Africa/Indonesia Working Paper No 4. 2008. http://www.ifpri.org/ publication/overview-poultry-sector-and-status-highly-pathogenic-avianinfluenza-hpai-kenya. Accessed 5 Jan 2019.

107. Alvarado CS, Gibbs SG, Gandara A, Flores C, Hurd WW, Green CF. The potential for community exposures to pathogens from an urban dairy. J Environ Health. 2012;74(7):22-8.

108. Fidan H. Cattle fattening systems and environmental regulations in Turkey. J Appl Biosci. 2010;(25):1579-84.

109. Kocaman I, Konukcu F, Ozturk G. Measures to Protect Environmental Problems Caused by Animal Wastes in Rural Settlement Areas: A Case Study from Western Turkey. J Anim Vet Adv. 2011;10(12):1536-42.

110. Polat HE, Olgun M. Assessment of Cattle Waste Management Systems Near Settlements in Central Anatolia, Turkey. J. Eng. Appl. Sci. 2007; 2(6):1103-10

111. Bennett E. Animal Agriculture Laws on the Chopping Block: Comparing United States and Brazil. Pace Environmental Law Review. 2014;31(2):531-63.

112. Silva RTBR, Naas IA, Neves DP. Selecting the best norms for broiler rearing welfare legislation. In: Precision Livestock Farming 2011 - Papers Presented 
at the 5th European Conference on Precision Livestock Farming, ECPLF 2011. Prague: Czech Centre for Science and Society; 2011. p. 522-7.

113. Humane Society International. An HSI Report: The Public Health Implications of Intensive Farm Animal Production in South Asia. 2013. http://www.hsi. org/assets/pdfs/hsi-fa-white-papers/public_health_impacts_of.pdf. Accessed 5 Jan 2019.

114. Chen D. Nutrition and feed strategies for sustainable swine production in China. Front Agric China. 2009:3(4):471-7.

115. Ellis LT, J. L. Surf and Turf: Environmental and Food Safety Concerns of China's Aquaculture and Animal Husbandry. 2007. https://www. wilsoncenter.org/sites/default/files/CES\%209\%20Feature\%20Article,\%20pp. \%2019-42.pdf. Accessed 5 Jan 2019.

116. Godfrey M. New laws put pressure on Chinese meat firms. Global Meat News. 2015. https://www.globalmeatnews.com/Article/2015/10/05/Newlaws-put-pressure-on-Chinese-meat-firms. Accessed 5 Jan 2019.

117. Burgo S, Otte J, Roland-Holst D. Poultry, HPAl and Livelihoods in Myanmar A Review. Mekong Team Working Paper No 8. 2009. https://assets. publishing.service.gov.uk/media/57a08b7340f0b64974000b6a/wp8_2009.pdf. Accessed 5 Jan 2019.

118. McOrist S, Khampee K, Guo A. Modern pig farming in the People's Republic of China: growth and veterinary challenges. Rev Sci Tech Oie. 2011;30(3): 961-8.

119. Pi C, Rou Z, Horowitz S. Fair or Fowl? Industrialization of Poultry Production in China. 2014. https://www.iatp.org/documents/fair-or-fowlindustrialization-poultry-production-china. Accessed 5 Jan 2019.

120. Alemu D, Degefe T, Ferede S, Nzietchueng S, Roy D. Overview and Background Paper on Ethiopia's Poultry Sector: Relevance for HPAI Research in Ethiopia. HPAl Africa/Indonesia Team Working Paper. 2008. https:// cgspace.cgiar.org/handle/10568/488. Accessed 5 Jan 2019.

121. Asresie A, Eshetu M, Adigrat E. Traditional Chicken Production System and Marketing in Ethiopia: A review. J Mark Consum Res. 2015;8:27-34.

122. Fitsum M, Aliy M. Poultry Production System and Role of Poultry Production in Tigray Region, Northern Ethiopia: A Review. J Biol Agric Healthc. 2014; 4(27):154.

123. Singh VP, Sharma VK, Sidhu MS, Kingra HS. Broiler Production in Punjab - An Economic Analysis. Agric. Econ. Res. Rev. 2010;23(2):315.

124. Food and Agriculture Organization of the United Nations. Pig sector: Kenya. 2012. http://www.fao.org/3/a-i2566e.pdf. Accessed 5 Jan 2019.

125. Kingdom of the Netherlands. Identification of livestock investment opportunities in Uganda. 2012. https://www.agriterra.org/assets/uploads/ 15820/Livestock\%20market\%20study.pdf Accessed 5 Jan 2019.

126. Tatwangire A. Successes and failures of institutional innovations to improve access to services, input and output markets for smallholder pig production systems and value chains in Uganda. 2013. https://cgspace.cgiar.org/handle/ 10568/33578. Accessed 5 Jan 2019.

127. Han JQ, Trienekens JH, Omta SWF. Relationship and quality management in the Chinese pork supply chain. Int. J. Prod. Econ. 2011;134(2):312-21.

128. Burgos S, Hanh PH, Roland-Holst D, Burgos S. Characterization of poultry production systems in Vietnam. Int. J. Poult. Sci. 2007;6(10):709-12.

129. Mengesha M. Chicken production scenarios and the headway options for improvement in Ethiopia. World Poultry Sci J. 2012;68(2):299-305.

130. Burgos S, Hinrichs JO, Pfeiffer D, Roland-Holst D. Poultry, HPAl and livelihoods in Viet Nam - A review. 2008. https://assets.publishing.service. gov.uk/media/57a08bbbed915d622c000e6d/wp02_2008.pdf. Accessed 5 Jan 2019.

131. Kinh LV, Hai LT. Improving pig performance through breeding and feeding in Vietnam. In: Pig systems in Asia and the Pacific: how can research and development enhance benefits to the poor? Volume 5 January 2019, edn: Institute of Agricultural Sciences of South Vietnam; 2008.

132. Tisdell CA. Structural transformation in the pig sector in an adjusting Vietnam market: a preliminary investigation of supply-side changes. 2008. https://cgspace.cgiar.org/handle/10568/2646. Accessed 5 Jan 2019.

133. Byrne J. Feed firms should get ready to leverage hog sector consolidation in Mexico: Rabobank. Feed Navigator. 2014. http://www.feednavigator.com/ Markets/Feed-firms-should-get-ready-to-leverage-hog-sector-consolidationin-Mexico-Rabobank. Accessed 5 Jan 2019.

134. Chacko CT, Gopikrishna P, Tiwari S, Ramesh V. Livestock in the changing landscape in India; its environmental, social and health consequences and responses - A case study. Working Paper 6. 2007. http://www.intercooperation.org.in/wp-content/themes/IC/images/ Livestock\%20in\%20the\%20changing.pdf. Accessed 21 May 2019.
135. United States Agency for International Development. Agricultural Growth Project-Livestock Market Development - Value Chain Analysis for Ethiopia. 2013. https://www.usaid.gov/sites/default/files/documents/1860/AGPLMD\%20Value\%20Chain\%20Analysis.pdf. Accessed 5 Jan 2019.

136. Tisdell CA. The survival of small-scale agricultural producers in Asia, particularly Vietnam: General issues illustrated by Vietnam's agricultural sector, especially its pig production. 2009. https://ideas.repec.org/p/ags/ uqseet/90625.html. Accessed 5 Jan 2019.

137. Tisdell CA. Trends in Vietnam's pork supply and structural features of its Pig Sector. Open Area Stud J. 2009;2:52-71.

138. Nalubwama SM, Mugisha A, Vaarst M. Organic livestock production in Uganda: potentials, challenges and prospects. Trop Anim Health Prod. 2011; 43(4):749-57.

139. Duc NV, Long T. Poultry production systems in Vietnam. 2008. http://www. fao.org/docrep/013/al693e/al693e00.pdf. Accessed 5 Jan 2019.

140. Alves-Pinto HNN. P. In: Certifying sustainability: opportunities and challenges for the cattle supply chain in Brazil; 2013. https://ccafs.cgiar.org/ publications/certifying-sustainability-opportunities-and-challenges-cattlesupply-chain-brazil\#.XC9-NM9KhTY. Accessed 5 Jan 2019.

141. Canan BT, Turhan, S. The evaluation of the Turkish broiler industry: the degree of market power. 2006. https://www.cabi.org/Uploads/animalscience/worlds-poultry-science-association/WPSA-italy-2006/10873.pdf. Accessed 5 Jan 2019.

142. Lundstrom M. Dynamics of the Livestock Revolution: Marginalization and Resistance in Southern Brazil. J Sustainable Agric. 2011;35(2):208-32.

143. Naas IA, Mantovani EC. Trends in Mechanization in Livestock Production in Brazil. Agric Mech Asia Africa Latin America. 2002;33:56-60.

144. Peel DS. The Mexican Cattle and Beef Industry: Demand, Production, and Trade. Western Econ Forum. 2005:4(1):14-18.

145. Turhan S, Ozbag BC, Cetin B. Analysis of the Turkish broiler sector: the case of price competition. N Z J Agric Res. 2006;49(4):431-7.

146. United Nations Conference on Trade and Development. Mexico's Agricultural Development: Perspectives and outlook. 2013. https://unctad. org/en/PublicationsLibrary/ditctncd2012d2 en.pdf Accessed 5 Jan 2019.

147. Roessler R, Herold P, Momm H, Valle Zárate A. Organisation of breeding under difficult framework conditions-the case of smallholder pig breeding in mountainous areas in Northwest Vietnam. Arch Anim Breed. 2012;55(6): 590-602

148. Byrne J. Cargill expands presence in Turkish premix market with acquisition. Feed Navigator. 2015. http://www.feednavigator.com/ Suppliers/Cargill-expands-presence-in-Turkish-premix-market-withacquisition. Accessed 5 Jan 2019.

149. Kök MS. Application of Food Safety Management Systems (ISO 22000/ HACCP) in the Turkish Poultry Industry: A Comparison Based on Enterprise Size. J Food Prot. 2009:72(10):2221-5.

150. Chaddad FR, Jank MS: The Evolution of Agricultural Policies and Agribusiness Development in Brazil. In: Choices. vol. 21; 2006

151. Schneider M. Developing the meat grab. J Peasant Stud. 2014;41(4):613-33.

152. Desvaux S, Ton VD, Thang PD, Hoa PTT. A general review and description of the poultry production in Vietnam. 2008. http://agritrop.cirad.fr/562460/1/ document 562460.pdf. Accessed 5 January 2019.

153. Costales AC, M. A. O. Contract Farming as an Institution for Integrating Rural Smallholders in Markets for Livestock Products in Developing Countries: (II) Results in Case Countries. 2009. http://www.fao.org/3/abp264e.pdf. Accessed 5 Jan 2019

154. Brazilian Poultry Association. Brazilian Poultry. Issue. 2012:1 http://www. brazilianchicken.com.br/files/publicacoes/ a73f38b2e3b9c4140fea2045c0d0a52e.pdf. Accessed 5 Jan 2019.

155. Ahuja V, Arindam S. Scope and Space for small scale poultry production in developing countries. 2007. http://www.fao.org/AG/ AGAlnfo/home/events/bangkok2007/docs/part3/3_3.pdf. Accessed 5 Jan 2019

156. Birthal PS, Taneja VK, Thorpe W. Smallholder livestock production in India: Opportunites and challenges. 2006. https://cgspace.cgiar.org/handle/10568/ 27769. Accessed 5 Jan 2019.

157. Wilson RT. Poultry production and performance in the Federal Democratic Republic of Ethiopia. World Poultry Sci J. 2010;66(3):441-53.

158. Ministry of Agriculture, International Livestock Research Institute. Animal production vision and strategy for Ethiopia. Ethiopia Livestock Master Plan Background Paper. 2013. https://cgspace.cgiar.org/handle/10568/ 67250. Accessed 5 Jan 2019. 
159. Ministry of Agriculture, International Livestock Research Institute. Live animals and meat value chain vision and strategy for Ethiopia. Ethiopia Livestock Master Plan Background Paper. 2013. https://cgspace.cgiar.org/ handle/10568/67254. Accessed 5 Jan 2019.

160. Tiongco M, Lapar M, Costales A, Son N, Jabbar M, Staal S. Is contract farming really pro-poor? Empirical evidence from Northern Vietnam. Association of Agricultural Economists Conference. 2009. https:// ageconsearch.umn.edu/record/51161/files/Ref361-Tiongco_et_al_2008_ Is\%20Contract\%20Farming\%20Really\%20Propoor.pdf. Accessed 5 Jan 2019.

161. Catelo MAO, Costales A. Contract farming and other market institutions as mechanisms for integrating smallholder livestock producers in the growth and development of the livestock sector in developing countries. FAO, ProPoor Livestock Policy Initiative, PPLPI Working Paper. 2008. http://www.fao. org/3/a-bp187e.pdf. Accessed 5 Jan 2019.

162. Ali J, Singh SP, Muhammad S. High-Value Agriculture and Structural Changes in the Indian Meat Industry: Implications for Agribusiness and Small Farmers. Journal of Food Distribution Research. 2007:38(1):1-9.

163. Gebremariam S, Amare S, Baker D, A. S. Diagnostic study of live cattle and beef production and marketing: Constraints and opportunities for enhancing the system. 2010. https://cgspace.cgiar.org/handle/10568/24698. Accessed 5 Jan 2019.

164. Government of India Planning Commission. Report of the Working Group on Animal Husbandry \& Dairying 12th Five Year Plan (2012-2017). 2011. http://planningcommission.gov.in/aboutus/committee/wrkgrp12/agri/AHD_ REPORT_Final_rev.pdf. Accessed 5 Jan 2019.

165. Selli F, Eraslan $H_{H}$, Chowdhury D, Sukumar A. International Competitiveness: Analysis of Turkish Animal Husbandry: An Empirical Study in GAP Region Enterprise. Risk Management. 2010;2(1):100-114.

166. Schneider M. Feeding China's Pigs: Implications for the Environment, China's Smallholder Farmers and Food Security. 2011. https://www.iatp.org/ documents/feeding-china\%E2\%80\%99s-pigs-implications-for-theenvironment-china\%E2\%80\%99s-smallholder-farmers-and-food. Accessed 5 Jan 2019.

167. Sharma S. The Need for Feed: China's Demand for Industrialized Meat and Its Impacts. 2014. https://www.iatp.org/documents/need-feed-chinasdemand-industrialized-meat-and-its-impacts. Accessed 5 Jan 2019.

168. Cherubini E, Zanghelini GM, Alvarenga RAF, Franco D, Soares SR. Life cycle assessment of swine production in Brazil: a comparison of four manure management systems. J Clean Prod. 2015;87:68-77.

169. Hernandez G, Branson A. Mexico: Livestock and Products Annual - Pork Production Grows while Beef Falls. USDA Foreign Agricultural Service. 2012.

170. Turkey Prime Ministry. Food \& Agriculture in Turkey. 2014. https://www. scribd.com/document/330506920/Food-and-Agriculture-industry. Accessed 5 Jan 2019.

171. Tuoi Tre News. Vietnam to spend nearly $\$ 5 b n$ on meat, animal feed material imports in 2014. 2014. https://tuoitrenews.vn/business/23303/ window.print(): Accessed 5 Jan 2019.

172. Byrne J. Acquisition leaves Masan Group a major feed player in Vietnam. Feed Navigator. https://www.feednavigator.com/Article/2015/04/28/ Acquisition-leaves-Masan-Group-a-major-feed-player-in-Vietnam. Accessed 10/15/15:

173. Nandudu P. Parliament told to speed up law on animal feeds. New Vision. http://www.newvision.co.ug/news/658257-parliament-told-to-speed-up-lawon-animal-feeds.html. Accessed 10/15/15:

174. Kagolo F. Fake feeds: Why your animals, birds are stunned, dying. New Vision. http://www.newvision.co.ug/news/635302-fake-feeds-why-youranimals-birds-are-stunned-dying.html. Accessed 10/15/15:

175. Brighter Green. Climate, food security, and growth: Ethiopia's complex relationship with livestock. 2011. http://www.brightergreen.org/files/ ethiopia_bg_pp_2011.pdf. Accessed 5 Jan 2019.

176. Halima H, Neser FWC, Van Marle-Koster E, De Kock A. Village-based indigenous chicken production system in north-west Ethiopia. Trop Anim Health Prod. 2007;39(3):189-97.

177. Mengesha M. Feed resources and chicken production in Ethiopia. World Poultry Sci J. 2012;68(3):491-502.

178. Ministry of Agriculture, International Livestock Research Institute. Animal production vision and strategy for Ethiopia. Ministry of Agriculture and Nairobi, Kenya: ILRI. 2013.

179. Birhan M, Adugna T. Livestock Feed Resources Assessment, Constraints and Improvement Strategies in Ethiopia. Middle East Journal of Scientific Research. 2014;21(4):616.
180. Hu YN, Cheng HF. Research Opportunities for Antimicrobial Resistance Control in China's Factory Farming. Environ Sci Technol. 2014;48(10):5364-5.

181. Huffstutter PJ, Baertlein L. Analysis: Behind China's U.S. pork deal, fears over feed additives: Reuters. http://www.reuters.com/article/2013/05/30/us-usasmithfield-ractopamine-analysis-idUSBRE94T03520130530. Accessed 15 Oct 2015

182. Krishnasamy V, Otte J, Silbergeld E. Antimicrobial use in Chinese swine and broiler poultry production. Antimicrob Resist Infect Control. 2015;4:17.

183. Lam HM, Remais J, Fung MC, Xu L, Sun SS. Food supply and food safety issues in China. Lancet. 2013;381(9882):2044-53.

184. Liu Y, Liu K, Lai J, Wu C, Shen J, Wang Y. Prevalence and antimicrobial resistance of Enterococcus species of food animal origin from Beijing and Shandong Province, China. J Appl Microbiol. 2013;114(2):555-63.

185. Zhang JJ, Wang LX, Ruan WK, An J. Investigation into the prevalence of coccidiosis and maduramycin drug resistance in chickens in China. Vet Parasitol. 2013;191(1-2):29-34.

186. Zhu YG, Johnson TA, Su JQ, Qiao M, Guo GX, Stedtfeld RD, Hashsham SA, Tiedje JM. Diverse and abundant antibiotic resistance genes in Chinese swine farms. Proc Natl Acad Sci U S A. 2013;110(9):3435-40.

187. Li YX, Chen TB. Concentrations of additive arsenic in Beijing pig feeds and the residues in pig manure. Resour Conserv Recy. 2005:45(4):356-67.

188. Byrne J. Cargill talks gut health, rumen functionality and antioxidants. Feed Navigator. 2014. http://www.feednavigator.com/Manufacturers/Cargill-talksgut-health-rumen-functionality-and-antioxidants. Accessed 5 Jan 2019.

189. Sambo E, Bettridge J, Dessie T, Amare A, Habte T, Wigley P, Christley RM. Participatory evaluation of chicken health and production constraints in Ethiopia. Prev Vet Med. 2015;118(1):117-27.

190. Tadesse D, Sing H, Mengistu A, Esatu W, Dessie T. Study on management practices and marketing systems of village chicken in East Shewa. Ethiopia. African Journal of Agricultural Research. 2013;8(22):2696-702.

191. Johnson T. Banned growth chemical remains a problem in beef in central Mexico. McClatchy DC. 2014; http://www.mcclatchydc.com/news/nationworld/world/latin-america/article24774313.html. Accessed 5 Jan 2019.

192. Byarugaba DK, Kisame R, Olet S. Multi-drug resistance in commensal bacteria of food of animal origin in Uganda. Afr J Microbiol Res. 2011;5(12): 1539-48.

193. Dione MM, Ouma EA, Lule P, Pezo D. Animal health services delivery systems and disease surveillance in the smallholder pig value chain in Uganda. 2014. https://cgspace.cgiar.org/handle/10568/35661. Accessed 5 Jan 2019.

194. Majalija S, Francis O, Sarah WG, Musisi-Lubowa, Vudriko P, Nakamya FM. Antibiotic susceptibility profiles of fecal escherichia coli isolates from diplitter broiler chickens in Northern and Central Uganda. Vet Res. 2010;3(4):7580.

195. Mangheni MN. Review of the Uganda smallholder pig value chain assessment results and suggested potential interventions to improve women's access and control of resources in the pig value chain. 2014 https://cgspace.cgiar.org/handle/10568/56899. Accessed 5 Jan 2019.

196. Mugga R. Rising demand for Ugandan poultry requires better practices World Poultry 2007;23(2):10-11.

197. Carrique-Mas JJ, Trung NV, Hoa NT, Mai HH, Thanh TH, Campbell Jl, Wagenaar JA, Hardon A, Hieu TQ, Schultsz C. Antimicrobial usage in chicken production in the Mekong Delta of Vietnam. Zoonoses and Public Health. 2015;62(S1):70-8.

198. RBTRd S, Nääs IA, DJd M. Broiler and swine production: animal welfare legislation scenario. Scientia Agricola. 2009;66:713-20.

199. Jourdan A. Overcrowding on farms behind mystery of China's floating pigs Reuters. 2013. http://www.reuters.com/article/2013/04/24/us-china-farmingpigs-idUSBRE93N1C720130424. Accessed 5 Jan 2019.

200. Chanie M, Negash T, Tilahun SB. Occurrence of concurrent infectious diseases in broiler chickens is a threat to commercial poultry farms in Central Ethiopia. Trop Anim Health Prod. 2009:41(7):1309-17.

201. Mehta RN, R. G. The Poultry Industry in India. 2007. http://www.fao.org/ Ag/AGAlnfo/home/events/bangkok2007/docs/part1/1_5.pdf. Accessed 5 Jan 2019

202. Mehta R, Narrod CA, Tiongco MM. Livestock Industrialization, Trade and SocialHealth-Environment Impacts in Developing Countries: A Case of Indian Poultry Sector. 2008. https://mpra.ub.uni-muenchen.de/32678/. Accessed 5 Jan 2019.

203. Compassion in World Farming Trust. Animal Welfare Aspects of Good Agricultural Practice: Pig production. 2006. https://www.ciwf.org.uk/media/ 5492194/gap_pig_book_full.pdf Accessed 5 Jan 2019. 
204. Humane Society International. An HSI Report: Adopting a Cage-Free Production Policy for Animal Products in Brazil. 2010. http://www.hsi.org/ assets/pdfs/an_hsi_report_adopting_a.pdf. Accessed 5 Jan 2019

205. Godfrey M. Chinese Department of Agriculture predicts lower pork prices. Global Meat News. 2014. http://www.globalmeatnews.com/ Industry-Markets/Low-prices-and-gloomy-outlook-for-China-s-pigs. Accessed 5 Jan 2019

206. Singh KM, Meena MS, Singh RKP. Livestock Value Chains: Prospects, Challenges and Policy Implications for Eastern India. 2012. https://papers. ssrn.com/sol3/papers.cfm?abstract_id=2020916. Accessed 5 Jan 2019.

207. Ferraz JB, Felicio PE. Production systems--an example from Brazil. Meat Sci. 2010;84(2):238-43.

208. Turkish Ministry of Food, Agriculture and Livestock. Turkish Breeding Situation and What Will Be Development Plans for the Beef Production? 2013. http://www.interbev.fr/wp-content/uploads/2013/09/Turkish-BreedingSituation.pdf. Accessed 5 Jan 2019.

209. Uganda MR. Luweero District Gets Sh26 Billion Ultra-Modern Chicken Farm. All Africa. 2014; http://allafrica.com/stories/201409250445.html. Accessed 5 Jan 2019.

210. Ochalla N. Ethiopia's Land Grabs: Stories from the displaced. Intercontinental Cry Magazine. 2013. https://intercontinentalcry.org/ethiopias-land-grabsstories-displaced-20830/. Accessed 5 Jan 2019.

211. Smaller C, Wei Q, Yalan L. Farmland and Water: China invests abroad. 2012 https://www.iisd.org/pdf/2012/farmland_water_china_invests.pdf. Accessed 5 Jan 2019

212. Mubiru R, Namirimu T, Owino S, Kyalingonza L, Nyadoi P, Buyinza J. From extensive to semi-intensive livestock production systems in Uganda's Albertine Rift. 2013. http://www.uws.or.ug/wp-content/themes/UWS/PDFs/ LIVESTOCK\%20MANAGEMENT\%20EXTENSION\%20MANNUAL\%202013\% 20UWS-1.pdf. Accessed 5 Jan 2019

213. Benson T, Mugarura S. Livestock development planning in Uganda: Identification of areas of opportunity and challenge. Land Use Policy. 2013; 35:131-9.

214. Meyer $P$, Rodrigues P. Progress in the Brazilian cattle industry: an analysis of the Agricultural Censuses database. Animal Production Science. 2014;54(9): $1338-44$.

215. National Academy of Agricultural Sciences India. State of Indian Agriculture 2011-2012. 2012. https://www.indiawaterportal.org/sites/indiawaterportal. org/files/state-of-indian-agriculture-report-naas-2011-2012.pdf. Accessed 5 Jan 2019.

216. Cohn AS, Mosnier A, Havlik P, Valin H, Herrero M, Schmid E, O'Hare M, Obersteiner M. Cattle ranching intensification in Brazil can reduce global greenhouse gas emissions by sparing land from deforestation. Proc Natl Acad Sci U S A. 2014;111(20):7236-41.

217. Latawiec AE, Strassburg BB, Valentim JF, Ramos F, Alves-Pinto HN. Intensification of cattle ranching production systems: socioeconomic and environmental synergies and risks in Brazil. Animal. 2014;8(8):125563.

218. Martha GB, Alves E, Contini E. Land-saving approaches and beef production growth in Brazil. Agr Syst. 2012;110:173-7.

219. Martha GB, Alves ERdA, Contini E. Brazilian Beef Industry and the Economy of Natural Resources. 2011. https://www.infoteca.cnptia.embrapa.br/handle/ doc/908625. Accessed 5 Jan 2019.

220. Millen DD, Pacheco RDL, Marques MP, Rodrigues PHM, Arrigoni MDB. Current outlook and future perspectives of beef production in Brazil. Animal Frontiers. 2011;1(2):46-52.

221. Schmidt GS. Swine Production and Manure Management in Brazil. 2009. https://labexkorea.files.wordpress.com/2009/12/swine_manure.pdf Accessed 5 Jan 2019.

222. Qiu HG, Liao SP, Jing Y, Luan J. Regional differences and development tendency of livestock manure pollution in China. J Environ Sci (China). 2013; 34(7):2766-74

223. Porphyre V, Médoc J-M. Outlook for an integrated sustainable development of pig production in the Red River Delta. 2006. http://hal. cirad.fr/cirad-00168389. Accessed 5 Jan 2019.

224. Humane Society International. HSI Fact Sheet: Pig Factory Farming in Mexico. 2012. http://www.hsi.org/assets/pdfs/pig_factory_farming_in_ mexico.pdf. Accessed 5 Jan 2019.

225. Food and Agriculture Organization of the United Nations and International Atomic Energy Agency. Guidelines for sustainable manure management in Asian livestock production systems. 2008. https://www-
pub.iaea.org/MTCD/Publications/PDF/TE_1582_web.pdf. Accessed 5 Jan 2019.

226. Ponette-Gonzalez AG, Fry M. Pig pandemic: Industrial hog farming in eastern Mexico. Land Use Policy. 2010;27(4):1107-10.

227. Perrett M. Australia signs pioneering cattle deal with China. Global Meat News. 2015. http://www.globalmeatnews.com/Industry-Markets/Australiasigns-pioneering-cattle-deal-with-China. Accessed 5 Jan 2019.

228. Godfrey M. China tackles over-capacity issues. Global Meat News. 2015. http:// www.globalmeatnews.com/Industry-Markets/China-tackles-over-capacityissues. Accessed 5 Jan 2019.

229. Meat+Poultry. Russia mulls ban of Brazilian and Canadian pork Meat + Poultry. 2014. https://www.meatpoultry.com/articles/11277-russia-mulls-banof-brazilian-canadian-pork. Accessed 5 Jan 2019.

230. Perkins C. Russia set to lift Brazilian meat embargo. Global Meat News. 2012. http://www.globalmeatnews.com/Industry-Markets/Russia-set-to-liftBrazilian-meat-embargo. Accessed 5 Jan 2019

231. Vorotnikov V. Russia may ban meat imports from Brazil. Global Meat News. 2013. http://www.globalmeatnews.com/Industry-Markets/Russia-may-banmeat-imports-from-Brazil. Accessed 5 Jan 2019.

232. Perkins C. Rise in Brazilian beef and poultry exports. Global Meat News. 2013. http://www.globalmeatnews.com/Industry-Markets/Rise-in-Brazilianbeef-and-poultry-exports. Accessed 5 Jan 2019.

233. Bonsall L. Brazilian beef: The China of Latin America? Global Meat News. 2012. http://www.globalmeatnews.com/Analysis/Brazilian-beef-The-China-ofLatin-America. Accessed 5 Jan 2019.

234. Vesilind PA. NAFTA's Trojan Horse \& the Demise of the Mexican Hog Industry. University of Miami Inter-American Law Review. 2011:42(2):1-23.

235. Alemayehu K. Value chain assessment of beef cattle production and marketing in Ethiopia: Challenges and opportunities of linking smallholder farmers to the markets. Livestock Research for Rural Development. 2011;23(12).

236. Nguyen VT, Carrique-Mas JJ, Ngo TH, Ho HM, Ha TT, Campbell Jl, Nguyen TN, Hoang NN, Pham VM, Wagenaar JA. Prevalence and risk factors for carriage of antimicrobial-resistant Escherichia coli on household and smallscale chicken farms in the Mekong Delta of Vietnam. J Antimicrob Chemother. 2015;70(7):2144-52.

237. Trach NX. Possible consequences of inappropriate intensification of animal production in Vietnam and approaches to a void. Livestock Research for Rural Development. 2003;15(1):1-7.

238. Gerbens-Leenes PW, Mekonnen MM, Hoekstra AY. The water footprint of poultry, pork and beef: A comparative study in different countries and production systems. Water Resources and Industry. 2013;(1-2):25-36.

239. Global Methane Initiative. Resource Assessment for Livestock and AgroIndustrial Wastes - Turkey. 2012. https://www.globalmethane.org/ documents/ag_turkey res assessment.pdf. Accessed 5 Jan 2019.

240. Ellis L. A CHINA ENVIRONMENTAL HEALTH PROJECT RESEARCH BRIEF: Environmental Health and China's Concentrated Animal Feeding Operations (CAFOs). 2007. https://www.wilsoncenter.org/sites/default/files/factory_ farms feb28.pdf. Accessed 5 Jan 2019.

241. Zhang XL, Li YX, Liu B, Wang J, Feng CH, Gao M, Wang LN. Prevalence of Veterinary Antibiotics and Antibiotic-Resistant Escherichia coli in the Surface Water of a Livestock Production Region in Northern China. PLoS One. 2014;9(11):e111026.

242. Brighter Green. Skillful Means: The Challenges of China's Encounter with Factory Farming. 2011. http://www.brightergreen.org/files/brightergreen_ china_print.pdf Accessed 5 Jan 2019.

243. Li XL, Yuan QH, Wan LQ, He F. Perspectives on livestock production systems in China. Rangeland J. 2008;30(2):211-20.

244. Garnett TW, A. Appetite for change: Social, economic and environmental transformations in China's food system. 2014. https://fcrn.org.uk/fcrn/ publications/appetite-for-change. Accessed 5 Jan 2019.

245. Yilmaz O, Wilson RT. The domestic livestock resources of Turkey: Economic and social role, species and breeds, conservation measures and policy issues. Livestock Res Rural Dev. 2012;24(9).

246. Wainaina P, Okello JJ, Nzuma JM. Blessing or Evil? Contract Farming, Smallholder Poultry Production and Household Welfare in Kenya. Q J Int Agric. 2014;53:319-340.

247. Nijdam D, Rood T, Westhoek H. The price of protein: Review of land use and carbon footprints from life cycle assessments of animal food products and their substitutes. Food Policy. 2012;37(6):760-70.

248. World Wildlife Fund. Soy and Deforestation. 2017. https://www.worldwildlife org/industries/soy. Accessed 5 Jan 2019. 
249. Erb K-H, Lauk C, Kastner T, Mayer A, Theurl MC, Haberl H. Exploring the biophysical option space for feeding the world without deforestation. Nature communications. 2016;7:11382.

250. Lassaletta L, Billen G, Grizzetti B, Garnier J, Leach AM, Galloway JN. Food and feed trade as a driver in the global nitrogen cycle: 50-year trends. Biogeochemistry. 2014;118(1):225-41.

251. Rae A. China's agriculture, smallholders and trade: driven by the livestock revolution?*. Aust J Agric Resour Econ. 2008;52(3):283-302.

252. McMichael $P$. The land grab and corporate food regime restructuring. The Journal of Peasant Studies. 2012;39(3-4):681-701.

253. Maron DF, Smith TJ, Nachman KE. Restrictions on antimicrobial use in food animal production: an international regulatory and economic survey. Globalization and health. 2013;9(1):48.

254. Bovet P, Paccaud F. Cardiovascular disease and the changing face of global public health: a focus on low and middle income countries. Public Health Rev. 2011;33(2):397.

255. Cook S, Silici L, Adolph B, Walker S. Sustainable intensification revisited. IIED Issue Paper; 2015.

256. Nadimpalli M, Delarocque-Astagneau E, Love DC, Price LB, Huynh B-T, Collard J-M, Lay KS, Borand L, Ndir A, Walsh TR. Combating Global Antibiotic Resistance: Emerging One Health Concerns in Lower-and Middle-Income Countries. Clin Infect Dis. 2018;66(6):963-969.

257. Ceryes CA, Heaney CD. "Ag-Gag" Laws: Evolution, Resurgence, and Public Health Implications. New Solut. 2019;28(4):664-82.

258. Ramos AK, Fuentes A, Carvajal-Suarez M. Self-reported occupational injuries and perceived occupational health problems among Latino immigrant swine confinement workers in Missouri. J Environ Public Health. 2018;2018.

259. Fagan KM, Hodgson MJ. Under-recording of work-related injuries and illnesses: An OSHA priority. J Saf Res. 2017;60:79-83.

260. Mora DC, Arcury TA, Quandt SA. Good job, bad job: Occupational perceptions among Latino poultry workers. Am J Ind Med. 2016;59(10): 877-86.

261. Douphrate DI, Stallones L, Lunner Kolstrup C, Nonnenmann MW, Pinzke S, Hagevoort GR, Lundqvist P, Jakob M, Xiang H, Xue L, et al. Work-Related Injuries and Fatalities on Dairy Farm Operations-A Global Perspective. J Agromed. 2013;18(3):256-64.

262. Smit LA, van der Sman-de Beer F, Opstal-van Winden AW, Hooiveld M, Beekhuizen J, Wouters IM, Yzermans J. Heederik D. Q fever and pneumonia in an area with a high livestock density: a large population-based study. PLoS One. 2012;7(6):e38843.

Ready to submit your research? Choose BMC and benefit from:

- fast, convenient online submission

- thorough peer review by experienced researchers in your field

- rapid publication on acceptance

- support for research data, including large and complex data types

- gold Open Access which fosters wider collaboration and increased citations

- maximum visibility for your research: over $100 \mathrm{M}$ website views per year

At BMC, research is always in progress.

Learn more biomedcentral.com/submissions 